\title{
Usage of Fermental Traps for the Study of the Species Diversity of Coleoptera
}

\author{
Alexander B. Ruchin $1, * \mathbb{C}$, Leonid V. Egorov ${ }^{1,2}$ and Anatoliy A. Khapugin 1,3 \\ 1 Joint Directorate of the Mordovia State Nature Reserve and National Park "Smolny", 430005 Saransk, Russia; \\ platyscelis@mail.ru (L.V.E.); hapugin88@yandex.ru (A.A.K.) \\ 2 Prisursky State Nature Reserve, 428034 Cheboksary, Russia \\ 3 Institute of Environmental and Agricultural Biology (X-BIO), Tyumen State University, \\ 625003 Tyumen, Russia \\ * Correspondence: ruchin.alexander@gmail.com
}

Citation: Ruchin, A.B.; Egorov, L.V.; Khapugin, A.A. Usage of Fermental Traps for the Study of the Species Diversity of Coleoptera. Insects 2021, 12, 407. https://doi.org/10.3390/ insects12050407

Academic Editor: Philippe Jeanneret

Received: 29 March 2021

Accepted: 28 April 2021

Published: 30 April 2021

Publisher's Note: MDPI stays neutral with regard to jurisdictional claims in published maps and institutional affiliations.

Copyright: (c) 2021 by the authors. Licensee MDPI, Basel, Switzerland. This article is an open access article distributed under the terms and conditions of the Creative Commons Attribution (CC BY) license (https:/ / creativecommons.org/licenses/by/ $4.0 /)$.
Simple Summary: This study describes how simple traps can be used to study tree crowns and undergrowth at low altitudes. They are used with bait made of fermenting liquids (beer, wine) with the addition of sugar and other carbohydrates. The research was conducted between 2018 and 2020 in several regions of Russia. It was possible to identify 294 species from 45 Coleoptera families during this time. Simple traps have been shown to be highly effective, and can be used to study insect biodiversity in forest ecosystems.

Abstract: The possibilities of applying various methods to study Coleoptera give unexpected and original results. The studies were carried out with the help of fermental crown traps in 2018-2020 on the territory of eight regions in the central part of European Russia. The biodiversity of the Coleoptera that fall into crown traps includes 294 species from 45 families. The number of species attracted to the fermenting bait is about a third of the total number of species in the traps (this is $97.4 \%$ of the number of all of the caught specimens). The largest number of species that have been found in the traps belong to the families Cerambycidae, Elateridae and Curculionidae. The most actively attracted species mainly belong to the families Cerambycidae, Nitidulidae and Scarabaeidae. The species of these families are equally attracted by baits made of beer, white and red wines. In order to identify the Coleoptera biodiversity of a particular biotope, two-year studies are sufficient, and they should be carried out throughout the vegetation season. Especially good results can be obtained from studies of rare species that are actively attracted by such baits. It is possible to study the vertical-horizontal distribution of Coleoptera fauna in individual biotopes.

Keywords: fermental traps; beer traps; Coleoptera; fauna; biodiversity; occurrence

\section{Introduction}

Forests are biologically diverse ecosystems that represent some of the richest communities of living organisms on Earth. Due to the diversity of these ecosystems, they are home to a significant species diversity of insects [1-8]. While many insect species thrive, some forest species are on the verge of extinction due to forest degradation, pollution, fragmentation, changes in tree composition, climate change, and other factors, such as fires, tree felling, and draining [9-16]. The species diversity of Coleoptera forest ecosystems is very large, and knowledge about this biodiversity is constantly being updated through the use of a wide variety of studying methods [17-22].

Entomological net mowing, window traps, pitfall traps, light traps, and Malaise traps are key methods for studying Coleoptera biodiversity in forest systems [23-28]. Most of these methods are easy to use, and therefore a huge number of studies are based on these research methods. At the same time, these methods are usually used at the level of human growth. These methods are quite accessible, and are actively used to study insects of the 
soil and herbaceous tiers, as well as-to a certain extent-shrubs and undergrowth. In open ecosystems, such as grasslands, steppes, and deserts, these methods are sufficient to study biodiversity [29-32].

However, these methods do not always accurately assess the biodiversity of Coleoptera in individual forest areas or in specific forest tiers. This is especially true for the study of the upper tiers of the forest, which are often inaccessible to the entomologist with a net. Some collection methods are quite labor-intensive, and are therefore rarely used by entomologists. Fermental crown traps with various baits are an additional and well-established method of studying the biodiversity of Coleoptera in the forest canopy [33]. Bait trapping for insects is discussed in many general entomological texts, and ranges from techniques such as 'sugaring' and pheromone traps to using 'natural' organic baits such as carrion and dung [34]. Traps with baits made of fermenting liquids, such as wine, molasses, and beer, with the addition of bananas, apples, sugar and other natural fillers have proven effective in detecting many Coleoptera families [35-43]. Previously, a mixture of beer with sugar, honey and jam was successfully used as bait [44-46]. Using such original and unusual collection methods, it is possible to find new species not only for the region, but also for science $[47,48]$. This study presents the results of studying Coleoptera using fermental crown traps in various regions of Central Russia and the Volga region.

\section{Materials and Methods}

\subsection{Placement of Traps}

The traps are a plastic $5 \mathrm{~L}$ container with a window cut out of it on one side at a distance of $10 \mathrm{~cm}$ from the bottom. With the help of a load, a rope with a tied trap was thrown onto a tree branch at a height of 5 to $12 \mathrm{~m}$ from the soil surface [46,49]. As bait, fermenting beer, white and red dry wine were used, with an addition in the form of honey, jam or sugar.

The traps were placed in eight regions: the Republic of Mordovia, and the Tambov, Saratov, Ryazan, Vladimir, Nizhny Novgorod, Ulyanovsk, and Penza regions in 2018 (from June to August), in 2019 (from April to October), and in 2020 (from April to October). The volume of material for this article is presented in Table 1.

Table 1. The quantity of the collected material in the regions of Russia *

\begin{tabular}{|c|c|c|c|c|}
\hline Region & 2018 & 2019 & 2020 & Total \\
\hline \multirow{2}{*}{ Republic of Mordovia } & $\underline{83}$ & 266 & $\underline{226}$ & $\underline{575}$ \\
\hline & $1 \overline{75} 0$ & $\overline{10,617}$ & $1 \overline{0,901}$ & 23,268 \\
\hline \multirow{2}{*}{ Penza region } & $\underline{0}$ & $\underline{18}$ & $\underline{86}$ & 104 \\
\hline & $\overline{0}$ & $\overline{495}$ & $4 \overline{968}$ & $\overline{5463}$ \\
\hline \multirow{2}{*}{ Ulyanovsk region } & $\underline{0}$ & 20 & 32 & 52 \\
\hline & $\overline{0}$ & $\overline{278}$ & $1 \overline{767}$ & $2 \overline{2045}$ \\
\hline \multirow{2}{*}{ Nizhny Novgorod region } & $\underline{0}$ & $\underline{13}$ & $\underline{29}$ & $\underline{42}$ \\
\hline & 0 & 265 & 880 & $\overline{1145}$ \\
\hline \multirow{2}{*}{ Vladimir region } & $\underline{0}$ & $\underline{0}$ & $\underline{21}$ & $\underline{21}$ \\
\hline & $\overline{0}$ & 0 & $\overline{143}$ & $\overline{143}$ \\
\hline \multirow{2}{*}{ Ryazan region } & $\underline{0}$ & $\underline{0}$ & $\underline{19}$ & $\underline{19}$ \\
\hline & $\overline{0}$ & 0 & 850 & $\overline{850}$ \\
\hline \multirow{2}{*}{ Saratov region } & $\underline{0}$ & $\underline{0}$ & $\underline{4}$ & $\underline{4}$ \\
\hline & $\overline{0}$ & $\overline{0}$ & $\overline{60}$ & 60 \\
\hline \multirow{2}{*}{ Tambov region } & $\underline{0}$ & $\underline{0}$ & $\underline{3}$ & $\underline{3}$ \\
\hline & $\overline{0}$ & $\overline{0}$ & 295 & 295 \\
\hline \multirow{2}{*}{ Total } & $\underline{83}$ & $\underline{317}$ & $\underline{420}$ & $\underline{820}$ \\
\hline & 1750 & 11,655 & 19,864 & 33,269 \\
\hline
\end{tabular}

* the number of traps installed is above the line; the number of recorded beetle samples is below the line. 


\subsection{Usage of Attractive Liquids}

Over several series of experiments, the most attractive liquids for Coleoptera were determined. The attractive liquids were white wine, red wine, and beer. The attraction mixture consisted of these liquids, with or without added sugar. The following variants of mixtures were studied:

(1) beer with sugar (BS),

(2) beer without sugar (B),

(3) red wine with sugar (RvS),

(4) red wine without sugar $(\mathrm{Rv})$,

(5) white wine with sugar (WvS),

(6) white wine without sugar (Wv).

These experiments were carried out from April to August (they were repeated 10 times). All of the traps in each series of experiments were located on oak trees at the same height $(5.5-6 \mathrm{~m})$ at a close distance from each other (no more than 10-15 m). Each repetition of the experiment (exposure) was carried out for 7-10 days. Each repetition was carried out within one biotope (on an area of no more than $500 \mathrm{~m}^{2}$ ).

\subsection{Calculations and Used Terms}

Several terms were used to determine the effectiveness of traps. Occurrence: the ratio of the number of samples in which a species (taxonomic group) is present to the total number of samples (expressed in \%). Exposure time: the period between hanging a trap and taking samples for analysis (expressed in days). Bait: a liquid that attracts insects, located in a trap, consisting of various mixtures (beer, wine, water) and natural fillers such as solid and liquid food additives (sugar, honey, jam).

\subsection{Format}

The classification of the family-group taxa used in this checklist follows predominantly Bouchard et al. [50], with subsequent additions [51]. Changes from the Catalog of Palaearctic Coleoptera are taken into account [52-58], as well as data on the Cucujoidea from the article by Robertson et al. [59], and Curculionoidea from the publication of Alonso-Zarazaga et al. [60]. In order to clarify the nomenclature, the cited articles were used, as well as the Catalog of Palaearctic Coleoptera [61,62]. Years of description of some species are specified by Bousquet [63]. All of the species identification was carried out by L.V. Egorov.

\section{Results}

During the experiments in 2018-2020, more than 33,000 Coleoptera (Appendix A) specimens fell into our traps. In total, 294 species from 45 families were recorded in the traps (Figure 1). About 1500 specimens could not be identified with regard to the species (mainly from the families Staphylinidae and Nitidulidae).

The largest number of species that were found in the traps belonged to the families Cerambycidae (57 species), Elateridae (33 species) and Curculionidae (31 species). However, the overwhelming number of families were represented in our catches by single species: only one species was recorded among 14 families (Staphylinidae, Hydrochidae, Monotomidae, Cucujidae, Lycidae, Brentidae, Attelabidae, Aderidae, Laemophloeidae, Boridae, Lymexylidae, Silvanidae, Mordellidae, Salpingidae), two species were recorded among 10 families (Erotylidae, Throscidae, Mycetophagidae, Scraptiidae, Pyrochroidae, Anthribidae, Cerylonidae, Melandryidae, Dytiscidae, Eucnemidae), and three species were recorded among three families (Scirtidae, Latridiidae, Ptinidae).

Based on our long-term research, we can distinguish between species that are attracted by the mix, and random species that fall for some other random reasons (for example, they stumble on the transparent walls of the trap or fly to the water). In some cases, when installing a trap, and during its prolonged exposure, especially in sunny places, the processes of the rotting of trapped insects can occur. This leads to the trapping of species that are attracted by carrion. We distinguish this group separately. 


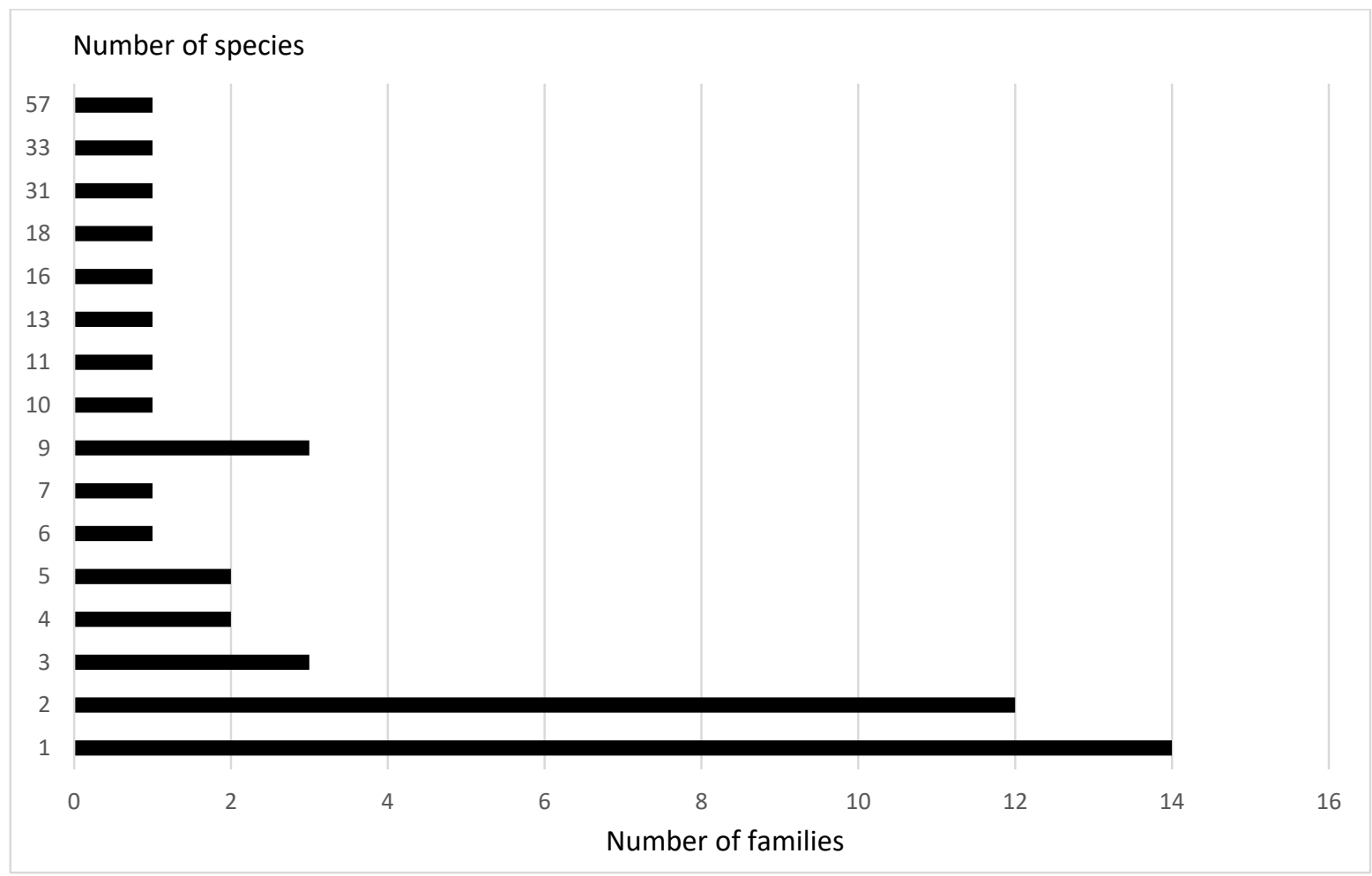

Figure 1. Distribution of the families by the number of captured species in the beer traps.

Thus, we conditionally distinguished three groups of Coleoptera species that fall into traps (Figure 2). The number of species attracted by the mix was $29.6 \%$ of the total number of species in the traps. However, they accounted for $97.4 \%$ of the number of samples that were identified. The average occurrence of these species exceeded the occurrence of random species by 21 times. The high occurrence of species that are attracted by carrion was noted. They probably react quickly enough to the prey and fall into the traps.

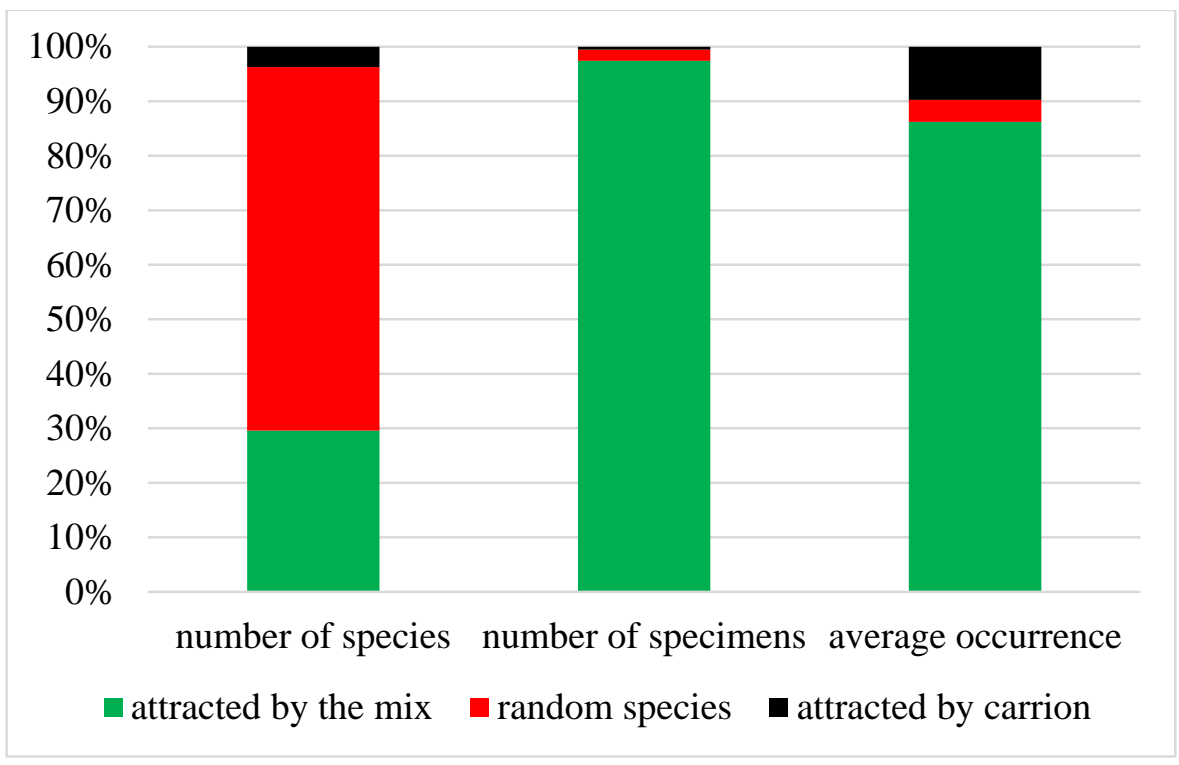

Figure 2. The ratio of the number of species, the number of specimens and the average occurrence of species, depending on the ability to attract to the bait.

As studies have shown (Figure 3), the increase in the number of traps in the third year did not have the same effect as in the first two years. From 2018 to 2020, we increased the number of traps set for the study of Coleoptera. We also increased the number of 
regions where these traps were located. It turned out that the number of species that fall into the traps increased significantly in the second year of the study, with an increase in the number of traps. However, in the third year of research, despite the higher number of traps, the number of new species that had not been caught before decreased. New species were trapped in 2020 due to an increase in the number of regions. Thus, in the third year, the number of new species caught in the traps decreased. They already included random and/or very rare species that live in this biotope. It can be concluded that two-year studies will be sufficient to study the biodiversity of a particular biotope or a small region. We used several compositions of mixtures, in which the basis was red wine, white wine or beer. Sugar and yeast were added as additives to this bait.

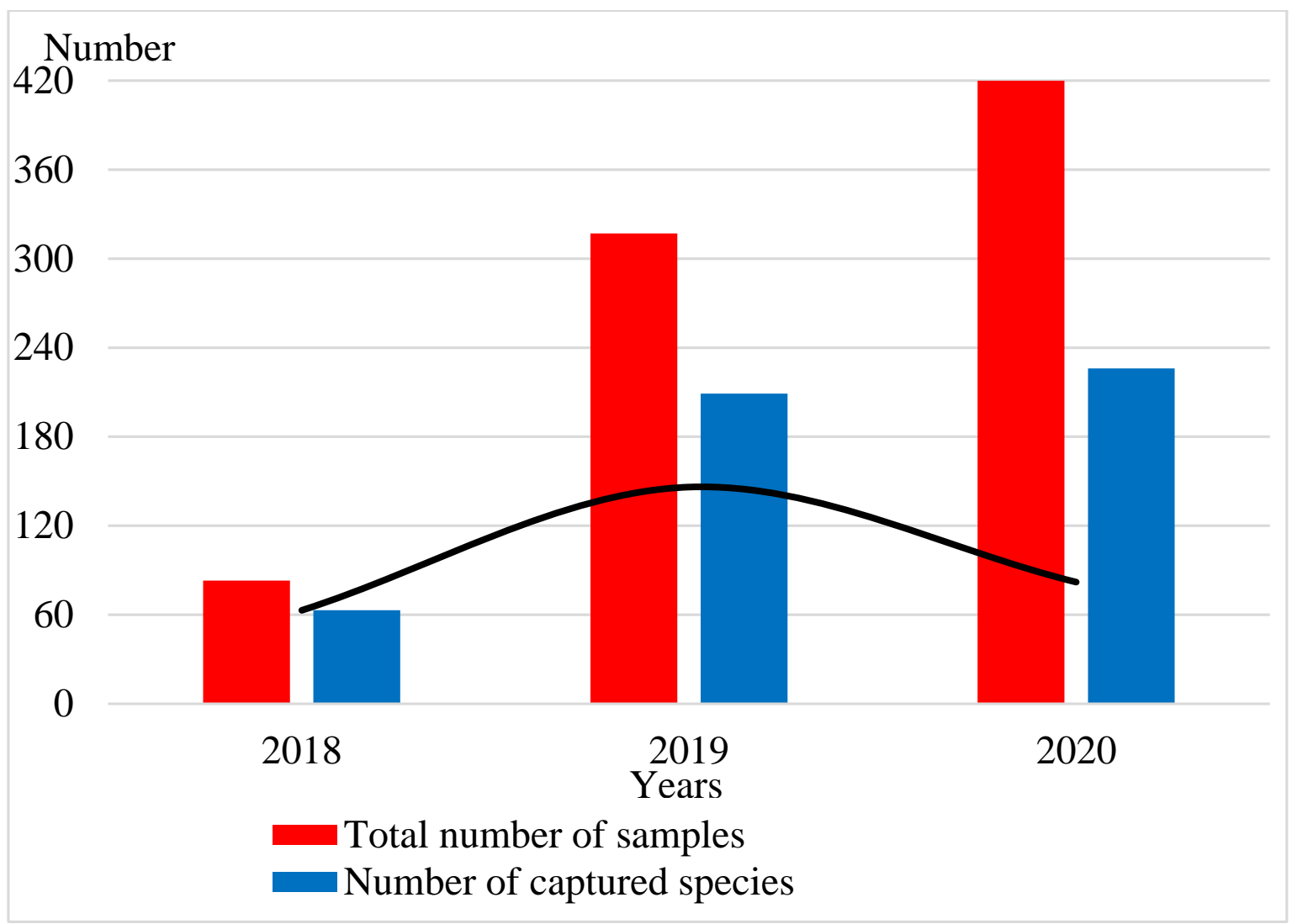

Figure 3. Dependence of the number of captured species on the number of traps by year.

Figure 4 shows the same direction of the effects of factors with some variance from $\mathrm{Wv}$ (above) to B (below all) for families and for species. It turned out that the number of Curculionidae specimens (mainly due to Anisandrus dispar) increases when catching with white wine without sugar, and to a lesser extent with red wine without sugar. At the same time, the number of Nitidulidae specimens is not related to these factors, but their catchability increases with all other factors. As for the other families, they are all equally attracted to baits from different mixtures. Thus, the Dermestidae, Scarabaeidae, Staphylinidae, and Cerambycidae are similarly attracted to beer- and wine-based baits.

Figure 5 shows the number of recorded specimens of various species, depending on the composition of the bait. It turned out that Cryptarcha strigata is better caught using the largest number of mixtures (B, BS, WvS, RVs), while Wv and Rv attract Anisandrus dispar, Protaetia marmorata and Xyleborus saxesenii to a lesser extent. However, most of the studied species were almost equally lured by the different mixtures. 


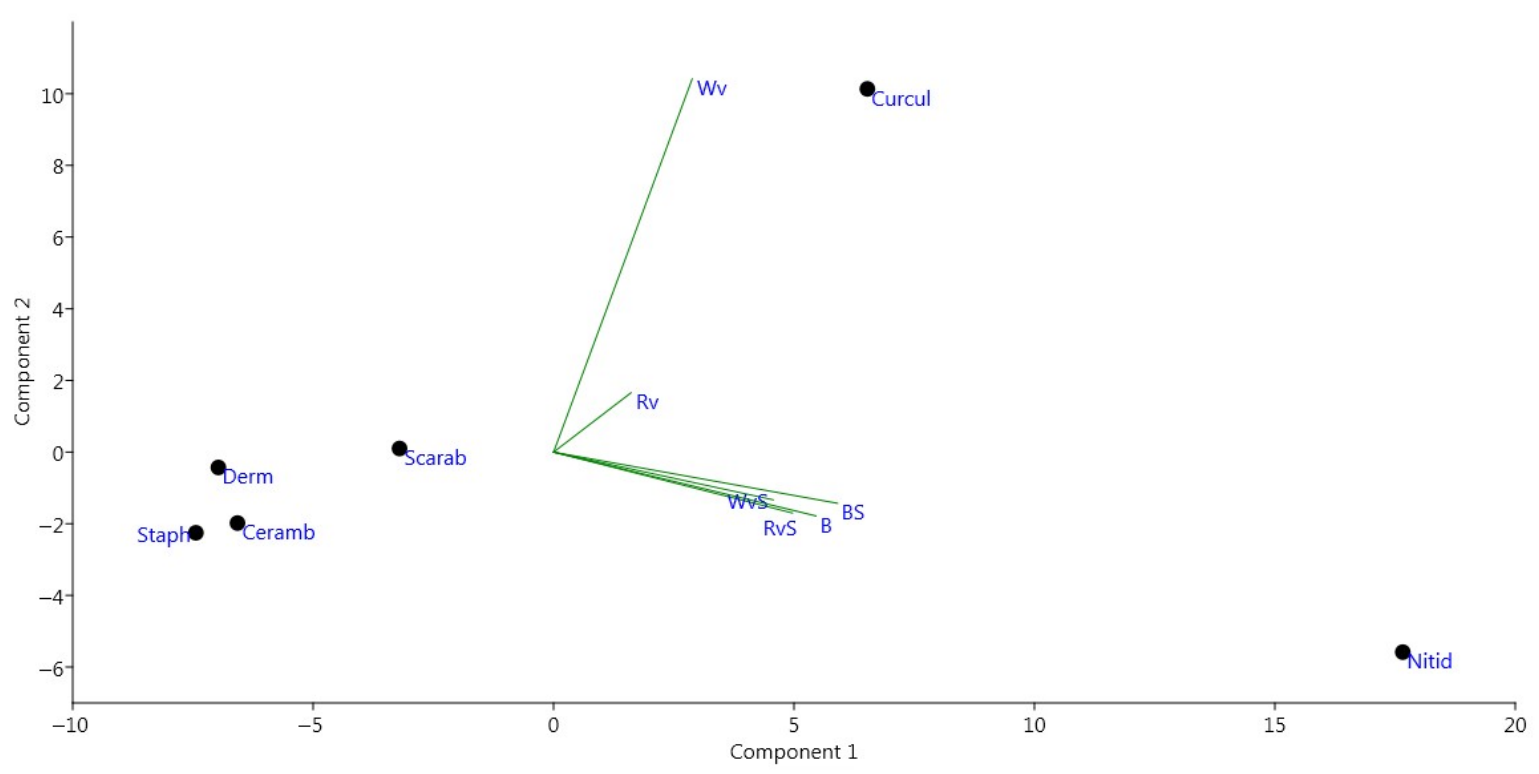

Figure 4. Canonical analysis of the number of registered specimens from different families, depending on the bait composition (beer with sugar (BS), beer without sugar (B), red wine with sugar (RVs), red wine without sugar (Rv), white wine with sugar (WvS), white wine without sugar (Wv)). Families: Derm—Dermestidae, Scarab—Scarabaeidae, Staph—Staphylinidae, Nitid—Nitidulidae, Ceramb—Cerambycidae, Curcul—Curculionidae.

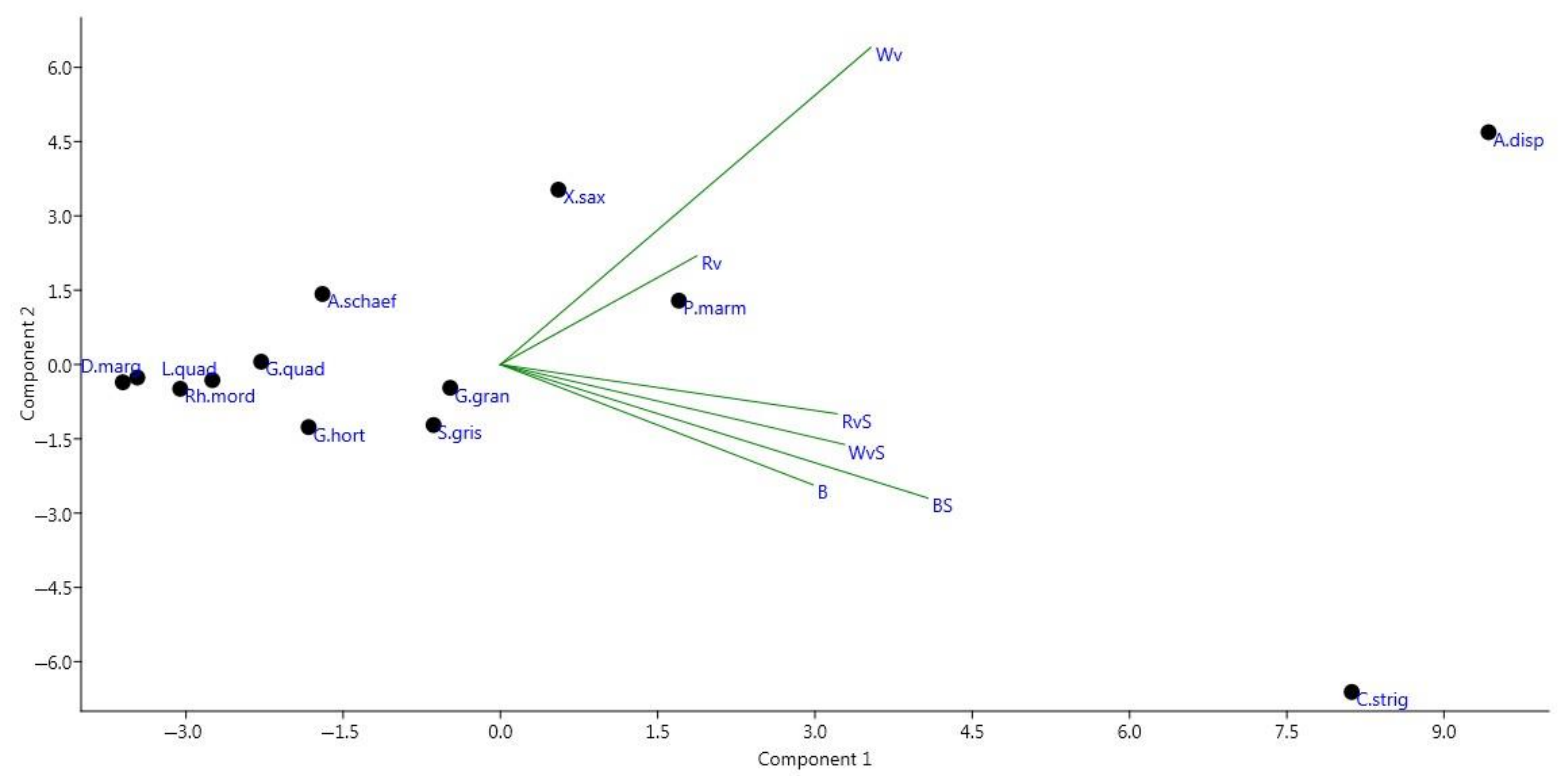

Figure 5. Canonical analysis of the number of recorded specimens of various species, depending on the composition of the bait (see the caption to Figure 4). Species: A.schaef-Attagenus schaefferi (Dermestidae), P.marm-Protaetia marmorata (Scarabaeidae), D.marg_Dalopius marginatus (Elateridae), C.strig-Cryptarcha strigata (Nitidulidae), G.hort-Glischrochilus hortensis (Nitidulidae), G.quad-Glischrochilus quadripunctatus (Nitidulidae), G.gran-Glischrochilus grandis (Nitidulidae), S.gris-Soronia grisea (Nitidulidae), L.thor-Leptura thoracica (Cerambycidae), L.quad-Leptura quadrifasciata (Cerambycidae), Rh.mord-Rhagium mordax (Cerambycidae), A.disp—Anisandrus dispar (Curculionidae), X.sax-Xyleborus saxesenii (Curculionidae).

Thus, the species composition of Coleoptera from fermental crown traps differs from those caught by other methods. Previously, such traps have been recommended for use in the study of rare insect species [46]. For example, we present the results of the study of rare species of Coleoptera, which are included or recommended in the Red Books of some regions [6,64-71] and the Red Data Book of Russia [72] (Table 2). 
Table 2. Occurrence of rare species (numbers indicate the number of rare species found in the region according to the fermental crown trap records).

\begin{tabular}{|c|c|c|c|c|c|c|c|c|c|}
\hline \multirow{2}{*}{ Species } & \multirow{2}{*}{$\begin{array}{c}\text { Red Data } \\
\text { Book of } \\
\text { Russia }\end{array}$} & \multicolumn{8}{|c|}{ Red Data Book } \\
\hline & & Vladimir Region & Ryazan Region & Republic of Mordovia & Penza Region & Nizhny Novgorod Region & Ulyanovsk Region & Saratov Region & Tambov Region \\
\hline \multicolumn{10}{|l|}{ Carabidae } \\
\hline Lebia marginata (Geoffroy, 1785) & - & - & - & $1(2)^{*}$ & - & - & - & - & - \\
\hline Quedius dilatatus (Fabricius, 1787) & - & - & - & $57(10)$ & - & - & $10(5)$ & - & - \\
\hline \multicolumn{10}{|l|}{ Silphidae } \\
\hline Dendroxena quadrimaculata (Scopoli, 1771) & - & $0(5)$ & - & $10(3)$ & - & - & - & - & - \\
\hline \multicolumn{10}{|l|}{ Lucanidae } \\
\hline Lucanus cervus (Linnaeus, 1758) & + & $0(1)$ & - & $0(3)$ & $0(25)$ & $0(2)$ & $3(43)$ & $0(30)$ & $0(7)$ \\
\hline \multicolumn{10}{|l|}{ Scarabaeidae } \\
\hline Gnorimus variabilis (Linnaeus, 1758) & - & $0(6)$ & $0(2)$ & $29(6)$ & $2(6)$ & - & $0(9)$ & $0(10)$ & $0(2)$ \\
\hline Osmoderma barnabita Motschulsky, 1845 & + & $0(3)$ & $0(9)$ & $3(4)$ & $0(7)$ & $0(11)$ & $0(7)$ & $0(5)$ & $0(1)$ \\
\hline Protaetia fieberi (Kraatz, 1880) & + & $7(4)$ & $5(-)$ & $125(12)$ & $48(6)$ & $11(-)$ & $40(-)$ & $2(9)$ & $1(-)$ \\
\hline Protaetia marmorata (Fabricus, 1792) & - & - & $15(7)$ & - & - & - & - & - & - \\
\hline Protaetia speciosissima (Scopoli, 1786) & + & $2(-)$ & $1(2)$ & $25(8)$ & $20(11)$ & $4(1)$ & $9(25)$ & $1(14)$ & $1(4)$ \\
\hline \multicolumn{10}{|l|}{ Elateridae } \\
\hline \multicolumn{10}{|l|}{ Coccinellidae } \\
\hline Adalia bipunctata (Linnaeus, 1758) & - & - & - & $1(4)$ & & - & - & - & - \\
\hline \multicolumn{10}{|l|}{ Cerambycidae } \\
\hline Leptura thoracica (Creutzer, 1799) & - & - & $6(2)$ & - & - & - & - & - & - \\
\hline Purpuricenus globulicollis Dejean, 1839 & - & - & - & - & $1(1)$ & - & - & - & $0(1)$ \\
\hline Purpuricenus kaehleri (Linnaeus, 1758) & - & - & $1(1)$ & $31(2)$ & - & - & - & - & $1(4)$ \\
\hline Necydalis major Linnaeus, 1758 & - & - & $0(7)$ & $32(8)$ & - & - & - & $0(8)$ & $0(6)$ \\
\hline Leptura aurulenta Fabricius, 1793 & - & - & - & $3(1)$ & - & - & - & - & - \\
\hline Aromia moschata (Linnaeus, 1758) & - & - & - & $30(10)$ & - & - & - & - & $0(8)$ \\
\hline \multicolumn{10}{|l|}{ Cleridae } \\
\hline Allonyx quadrimaculatus (Schaller, 1783) & - & - & - & $2(1)$ & - & $0(2)$ & - & - & - \\
\hline
\end{tabular}

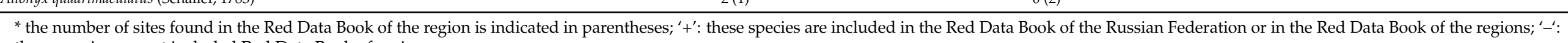
these species are not included Red Data Book of regions. 
In total, 18 species of Coleoptera which are included or are planned to be included in the Red Data Books, from nine families, were indicated in the studies. Especially significant are the results for the species that actively fly into crown traps for beer bait (Quedius dilatatus, Gnorimus variabilis, Protaetia fieberi, Protaetia marmorata, Protaetia speciosissima, Elater ferrugineus, Purpuricenus kaehleri, Necydalis major, Leptura aurulenta, Aromia moschata). The number of finds of such species increases significantly with an increase in the number of traps set. The use of such baits makes it possible to clarify even the status of species that have been included in the Red Data Books, and to suggest measures for their protection.

\section{Discussion}

Bait traps are an effective tool for the study of the insect fauna of the upper tiers of forests. Forest crowns are usually studied to a lesser extent than the soil and herbal layer $[73,74]$. Forest canopies did not attract researchers for a long time due to the logistical difficulties of reaching the tree crowns and the subsequent sampling problems. However, there were original research methods, including slingshots, crossbows, ropes, ladders, and networks of cranes, towers and passages which facilitate the work [75-78].

The active attraction of insects by baits based on fermenting beer and wine with the addition of sugar and other sweet substances, as well as fruits, can be explained. Many insects have receptors that perceive carbohydrates. According to many modern studies, insects have an excellent ability to perceive sugar [79-81]. Sweet carbohydrates play a crucial role in the life of insects as valuable energy and food resources. Insects always use the perception of sugars to assess the nutritional value of their food. Sugar and its decomposition products form the primary stimulatory signal for insect nutrition [82,83]. The use of traps with our baits is based on the perception of sugars as food components. We note that many other substances (alcohols, ketones, and other volatile substances) are released during fermentation, which can also attract insects [84-86].

However, not all insects are equally lured into such traps. There are species that are particularly common in traps, but a large number of specimens from the total number of species is attracted to bait in fermental crown traps.

Protaetia marmorata (Scarabaeidae)'s average occurrence was 72.2\% over three years. This species inhabits various types of forests, and is found in parks, shelterbelts, and other biotopes [87-89]. Its larval development occurs in the hollows of dead deciduous trees for three years $[87,89]$. In beer traps, this is the most common type. It actively flies into fermenting bait.

Cryptarcha strigata (Nitidulidae)'s average occurrence was 51.2\% over three years. It inhabits deciduous and mixed forests. Its imagos are often found near the effluents of the fermenting sap of $Q$. robur, where the preimaginal phases of this species develop. Occasionally, they are found on the leaking sap of $P$. tremula [90]. In beer traps, they are often found, sometimes in a very significant number.

Glischrochilus grandis (Nitidulidae)'s average occurrence $33.6 \%$ was over three years. It inhabits a wide variety of forest biocenoses. It is common on the leaking sap of various trees where the larvae develop. It is also known from tinder plants and from rotten berries, and develops on various decaying substrates [91-94]. It is caught in traps with vinegar bait [95]. The peak number in beer traps is typical in May-June, and single specimens are caught during all seasons.

Protaetia fieberi (Scarabaeidae)'s average occurrence was 30.9\% over three years. It inhabits various deciduous and mixed forests, and is common in parks and deciduous second-growth forest. The larvae of this species are supraciliary. The larvae and frass inhabit the tree hollows (Quercus, Tilia, Fagus, Salix, Populus) made by various species of woodpeckers, owls, and small mammals [96]. Previously, it was considered rare. However, our studies have shown that this species occurs regularly in different biotopes in the center of European Russia [97].

Leptura quadrifasciata (Cerambycidae)'s average occurrence was 30.7\% over three years. It is found in a wide range of biotopes. The larvae develop in dead or rotting wood, 
especially in the lower parts of standing trees, stumps, fallen trunks and the branches of various trees (alder, aspen, poplar, birch (birch may be preferred to other trees), hazel, oak, sallow, beech, willow, and elder). It inhabits wet or dry woodlands [98].

Soronia grisea (Nitidulidae)'s average occurrence was $28.6 \%$ over three years. It is confined to oak forests and mixed stands with the presence of oak, where it is often found on the sap of Q. robur and Salix $[90,93,94]$. In Turkey, it was also caught on baits with beer in mixed forests and pine forests [99]. The peak number in beer traps is typical in May-June, and single specimens are caught during all seasons.

Glischrochilus hortensis (Nitidulidae)'s average occurrence was $28.5 \%$ over three years. It inhabits deciduous and mixed forests. Its imago are found on the fermenting sap of $Q$. robur and under the bark of fallen and dying trees of B. pendula and P. tremula. Larvae develop under the bark of dying and damaged trees of B. pendula, P. tremula, and Q. robur and in their fermented sap, and can also occur on fermented berries, vegetables, and mushrooms $[90,94,100]$. The peak number in beer traps is typical in May; single specimens are caught during all seasons.

Rhagium mordax (Cerambycidae)'s average occurrence was $26.2 \%$ over three years. It is one of the most common species. It inhabits mixed, deciduous forests, and pine forests of various types [101]. Its larvae develop under the bark of dead pine and deciduous trees [102]. It is regularly found in beer traps from the end of April to July.

Leptura thoracica (Cerambycidae)'s average occurrence was $25.2 \%$ over three years. It is considered a polyphage of deciduous trees (Populus, Betula, Tilia, Salix, Fagus). The larvae inhabit the dead, rotten wood of thick trunks [103-105]. It has been observed that mass collections of this species occur in places with a predominance of Betula sp. in the stand [106]. The species was previously found in single specimens when studying the territory by conventional methods (net fishing, light fishing, window fishing) [101]. The use of beer traps has shown that the species is quite common in a wide range of biotopes.

Cetonia aurata (Scarabaeidae)'s average occurrence was $18.0 \%$ over three years. It inhabits a wide range of biotopes. It is often found on the flowers from the families Umbelliferae, Rosacea, and Asteraceae, where they feed on pollen and nectar [107]. The larvae develop in rotting wood and decaying plant substances [108]. It is found in beer traps which are placed at low altitudes, most often up to $5 \mathrm{~m}$. It is rarely caught in very high-placed traps.

Quedius dilatatus (Staphylinidae)'s average occurrence was 15.4\% over three years. This species is associated with Vespa crabro nests, where its larvae feed on Diptera larvae in the nest debris [109]. Therefore, it is often found on tree trunks, near the nests of Vespa crabro, but it is also often observed in other places. It inhabits forest biocenoses. It is often observed on the trunks of trees in the leaking sap [110]. In beer traps, it is caught in summer.

Protaetia cuprea volhyniensis (Scarabaeidae)'s average occurrence was $14.9 \%$ over three years. It inhabits a wide variety of forest biocenoses. This is a myrmecophilic species; the larvae usually develop in active and abandoned anthills, and sometimes in sawdust and garbage heaps. It is quite common on flowering plants [111,112].

All of these species were trapped annually with approximately the same occurrence. It is highly likely that they will be caught if traps with fermenting liquid are set in a certain biotopes during the season of activity of these species. On the other hand, those species can be caught that are very rare in the studied territory. For example, very rare species (Allonyx quadrimaculatus, Anoplodera rufipes ventralis, Leptura aurulenta, Purpuricenus globulicollis) are practically not caught, despite the use of different methods. Other species which are not often detected with the help of other methods (Quedius dilatatus, Protaetia affinis, Protaetia fieberi, Protaetia speciosissima, Elater ferrugineus, Ctesias serra, Globicornis emarginata, Nacerdes carniolica, Purpuricenus kaehleri, Aromia moschata, Leptura thoracica, Necydalis major, Xylotrechus pantherinus) are well lured by wandering baits, and with the help of these baits their numbers can be estimated. 
The quality of the bait can affect both the number of individuals caught and the species. Many effective traps have been suggested in several studies. For example, pineapple traps attract Scyphophorus acupunctatus (Curculionidae) better than fermented maguey [113]. The vinegar-ethanol-apple mixture was much more effective in attracting Eucryptorrhynchus scrobiculatus (Curculionidae) [114]. Bardiani et al. [115] successfully used baits made from various wines, beer, and banana puree to catch Lucanus cervus (Lucanidae). Traps with baits made of beer, palm wine, and various fruits (banana, mango, papaya, or pineapple) were successfully used to catch Cetoniinae (Scarabaeidae) [116]. Other studies [117] have shown that there was the greatest species richness and abundance of Cetoniinae in traps with bait made from banana juice and sugar cane, pineapple and sugar cane, and only sugar cane juice compared to other baits. These results showed the importance of sugar cane juice, used either in isolation or as an additive in the fruit fermentation process, for effective sampling [117]. A mixture of banana, brown sugar, molasses, and baker's yeast was used to study Cerambycidae fauna [118]. On the other hand, Allemand and Aberlenc [35] used a mixture of beer and red wine in equal amounts to capture beetles without adding other ingredients (fruit flavors, sugar, honey). Thus, the species composition of Coleoptera in bait traps clearly depends on the specific composition of the bait itself [119]. Different fishing methods, when used correctly, can be effective tools, for example, in monitoring biodiversity and studying rare insect species that are difficult to detect by other methods $[44,120,121]$.

\section{Conclusions}

The biodiversity of Coleoptera that fall into crown traps is large. Over a three-year period, we observed 294 species from 45 families. Most families are represented by between one and three species. The number of species actively attracted to the bait is about a third of the total number of species in the traps. At the same time, they account for $97.4 \%$ of the number of specimens. Two-year studies are sufficient to identify the Coleoptera biodiversity of a particular biotope. However, they need to be conducted during the entire insect activity season. Such studies will fully characterize the Coleoptera fauna. The largest number of species found in the traps belonged to the families Cerambycidae, Elateridae, and Curculionidae. However, the actively attracted species mainly belonged to the families Cerambycidae, Nitidulidae and Scarabaeidae. The species of these families are equally attracted by baits made of beer, or white and red wines.

We recommend the use of fermental crown traps with beer and wine for ecological studies of the Coleoptera fauna. This method can be applied to study the seasonal and spatial characteristics of the fauna. Especially good results can be obtained from studies of rare species that are actively attracted by such baits. It is possible to study the verticalhorizontal distribution of fauna in individual biotopes.

Author Contributions: A.B.R.: conceptualization, methodology, investigation, validation, original draft preparation, funding acquisition; L.V.E.: methodology, formal analysis, validation, editing; A.A.K.: software, validation, editing. All authors have read and agreed to the published version of the manuscript.

Funding: The study was partially supported by grants from RSF (project 21-14-00189).

Institutional Review Board Statement: Not applicable.

Data Availability Statement: The data is available upon request from the corresponding author.

Conflicts of Interest: The authors declare no conflict of interest.

\section{Appendix A}

Biodiversity and occurrence of Coleoptera from fermental traps in the European part of Russia in 2018-2020. 
Table A1. Biodiversity and occurrence of Coleoptera from fermental traps in the European part of Russia in 2018-2020.

\begin{tabular}{|c|c|c|c|c|c|c|}
\hline \multirow[b]{2}{*}{ Family, Species } & \multicolumn{2}{|c|}{2018} & \multicolumn{2}{|c|}{2019} & \multicolumn{2}{|c|}{2020} \\
\hline & $\begin{array}{l}\text { Number of } \\
\text { Specimens }\end{array}$ & $\begin{array}{c}\text { Occurrence, } \\
\%\end{array}$ & $\begin{array}{l}\text { Number of } \\
\text { Specimens }\end{array}$ & $\begin{array}{c}\text { Occurrence, } \\
\%\end{array}$ & $\begin{array}{l}\text { Number of } \\
\text { Specimens }\end{array}$ & $\begin{array}{c}\text { Occurrence, } \\
\%\end{array}$ \\
\hline \multicolumn{7}{|l|}{ Carabidae } \\
\hline Dromius agilis (Fabricius, 1787) & & & & & 1 & 0.24 \\
\hline Dromius quadraticollis A. Morawitz, 1862 & & & 3 & 0.95 & & \\
\hline Harpalus distinguendus (Duftschmid, 1812) & & & & & 1 & 0.24 \\
\hline Harpalus signaticornis (Duftschmid, 1812) & & & 1 & 0.32 & & \\
\hline Harpalus xanthopus winkleri Schauberger, 1923 & & & & & 2 & 0.48 \\
\hline Lebia marginata (Geoffroy, 1785) & & & 1 & 0.32 & & \\
\hline Limodromus assimilis (Paykull, 1790) & & & & & 2 & 0.48 \\
\hline Limodromus krynickii (Sperk, 1835) & & & 1 & 0.32 & & \\
\hline Tachyta nana (Gyllenhal, 1810) & & & 1 & 0.32 & & \\
\hline \multicolumn{7}{|l|}{ Dytiscidae } \\
\hline Ilybius erichsoni (Gemminger \& Harold, 1868) & & & & & 1 & 0.24 \\
\hline Ilybius fuliginosus (Fabricius, 1792) & & & 1 & 0.32 & & \\
\hline \multicolumn{7}{|l|}{ Hydrochidae } \\
\hline Hydrochus brevis (Herbst, 1793) & & & 1 & 0.32 & & \\
\hline \multicolumn{7}{|l|}{ Histeridae } \\
\hline Atholus duodecimstriatus (Schrank, 1781) & & & 1 & 0.32 & & \\
\hline Gnathoncus buyssoni Auzat, 1917 & & & 7 & 1.89 & 6 & 1.19 \\
\hline Platysoma elongatum (Thunberg, 1787) & & & 8 & 1.58 & 4 & 0.71 \\
\hline Platysoma lineare Erichson, 1834 & & & 7 & 1.89 & 1 & 0.24 \\
\hline \multicolumn{7}{|l|}{ Silphidae } \\
\hline Dendroxena quadrimaculata (Scopoli, 1771) & & & 3 & 0.95 & 41 & 5 \\
\hline Necrodes littoralis (Linnaeus, 1758) & 2 & 2.4 & 21 & 1.58 & 45 & 4.76 \\
\hline Nicrophorus humator (Gleditsch, 1767) & 1 & 1.2 & & & 4 & 0.71 \\
\hline Nicrophorus interruptus Stephens, 1830 & & & & & 14 & 1.67 \\
\hline Nicrophorus sepultor Charpentier, 1825 & & & & & 1 & 0.24 \\
\hline Nicrophorus vespillo (Linnaeus, 1758) & & & & & 1 & 0.24 \\
\hline Nicrophorus vespilloides Herbst, 1783 & 20 & 2.4 & 3 & 0.32 & 4 & 0.71 \\
\hline Oiceoptoma thoracicum (Linnaeus, 1758) & 11 & 9.5 & 24 & 4.1 & 13 & 2.62 \\
\hline Silpha tristis Illiger, 1798 & & & & & 2 & 0.24 \\
\hline \multicolumn{7}{|l|}{ Staphylinidae } \\
\hline Staphylinidae sp. & 13 & 13.1 & 423 & 22.08 & 252 & 28.57 \\
\hline Philonthus sp. & 1 & 1.2 & & & & \\
\hline Quedius dilatatus (Fabricius, 1787) & 6 & 6 & 329 & 23.66 & 221 & 16.67 \\
\hline \multicolumn{7}{|l|}{ Lucanidae } \\
\hline Lucanus cervus (Linnaeus, 1758) & & & & & 4 & 0.71 \\
\hline Platycerus caprea (De Geer, 1774) & & & & & 1 & 0.24 \\
\hline Platycerus caraboides (Linnaeus, 1758) & & & 1 & 0.32 & 1 & 0.24 \\
\hline Sinodendron cylindricum (Linnaeus, 1758) & & & & & 1 & 0.24 \\
\hline \multicolumn{7}{|l|}{ Scarabaeidae } \\
\hline Cetonia aurata (Linnaeus, 1758) & 60 & 21.4 & 122 & 17.03 & 635 & 20.48 \\
\hline
\end{tabular}


Table A1. Cont.

\begin{tabular}{|c|c|c|c|c|c|c|}
\hline \multirow[b]{2}{*}{ Family, Species } & \multicolumn{2}{|c|}{2018} & \multicolumn{2}{|c|}{2019} & \multicolumn{2}{|c|}{2020} \\
\hline & $\begin{array}{l}\text { Number of } \\
\text { Specimens }\end{array}$ & $\begin{array}{l}\text { Occurrence, } \\
\%\end{array}$ & $\begin{array}{l}\text { Number of } \\
\text { Specimens }\end{array}$ & $\begin{array}{l}\text { Occurrence, } \\
\%\end{array}$ & $\begin{array}{l}\text { Number of } \\
\text { Specimens }\end{array}$ & $\begin{array}{l}\text { Occurrence, } \\
\%\end{array}$ \\
\hline Esymus pusillus (Herbst, 1789) & & & & & 1 & 0.24 \\
\hline Gnorimus variabilis (Linnaeus, 1758) & 16 & 7.1 & 33 & 5.99 & 12 & 2.14 \\
\hline Osmoderma barnabita Motschulsky, 1845 & & & 2 & 0.32 & & \\
\hline Protaetia affinis (Andersch, 1797) & 1 & 1.2 & & & 2 & 0.24 \\
\hline Protaetia fieberi $($ Kraatz, 1880) & 56 & 33.3 & 250 & 30.28 & 617 & 29.29 \\
\hline Protaetia marmorata (Fabricus, 1792) & 750 & 82.1 & 2443 & 67.51 & 2550 & 67.14 \\
\hline Protaetia speciosissima (Scopoli, 1786) & 16 & 10.7 & 64 & 8.52 & 34 & 5 \\
\hline Protaetia cuprea volhyniensis (Gory \& Percheron, 1833) & 13 & 11.9 & 100 & 17.03 & 327 & 15.71 \\
\hline Serica brunnea (Linnaeus, 1758) & & & 1 & 0.32 & 1 & 0.24 \\
\hline Trichius fasciatus (Linnaeus, 1758) & & & 4 & 1.26 & & \\
\hline \multicolumn{7}{|l|}{ Scirtidae } \\
\hline Contacyphon padi (Linnaeus, 1758) & & & 4 & 1.26 & & \\
\hline Contacyphon pubescens (Fabricius, 1792) & & & 3 & 0.63 & & \\
\hline Contacyphon sp. & & & 1 & 0.32 & 2 & 0.48 \\
\hline Microcara testacea (Linnaeus,1767) & 2 & 1.2 & 1 & 0.32 & 3 & 0.71 \\
\hline \multicolumn{7}{|l|}{ Buprestidae } \\
\hline Agrilus sulcicollis Lacordaire, 1835 & & & 2 & 0.63 & & \\
\hline Agrilus angustulus (Illiger, 1803) & & & & & 1 & 0.24 \\
\hline Anthaxia quadripunctata (Linnaeus, 1758) & & & & & 1 & 0.24 \\
\hline Buprestis haemorrhoidalis Herbst, 1780 & & & 1 & 0.32 & & \\
\hline Dicerca alni (Fischer von Waldheim, 1824) & & & 1 & 0.32 & & \\
\hline Phaenops cyanea (Fabricius, 1775) & & & 2 & 0.63 & & \\
\hline Trachys minutus (Linnaeus, 1758) & & & 1 & 0.32 & & \\
\hline \multicolumn{7}{|l|}{ Eucnemidae } \\
\hline Melasis buprestoides (Linnaeus, 1760) & & & & & 1 & 0.24 \\
\hline Otho sphondyloides (Germar, 1818) & & & 1 & 0.32 & & \\
\hline \multicolumn{7}{|l|}{ Throscidae } \\
\hline Trixagus sp. & & & 4 & 0.95 & 9 & 1.13 \\
\hline Aulonothroscus sp. & & & 1 & 0.32 & & \\
\hline \multicolumn{7}{|l|}{ Elateridae } \\
\hline Agriotes lineatus (Linnaeus, 1767) & & & & & 1 & 0.24 \\
\hline Agriotes obscurus (Linnaeus, 1758) & & & & & 1 & 0.24 \\
\hline Agrypnus murinus (Linnaeus, 1758) & & & 7 & 2.21 & 29 & 5.48 \\
\hline Ampedus balteatus (Linnaeus, 1758) & & & 2 & 0.63 & 5 & 1.19 \\
\hline Ampedus cinnabarinus (Eschscholtz, 1829) & & & 9 & 2.21 & 97 & 5 \\
\hline Ampedus elongatulus (Fabricius, 1787) & & & 3 & 0.95 & 1 & 0.24 \\
\hline $\begin{array}{l}\text { Ampedus nigerrimus (Lacordaire in Boisduval \& } \\
\text { Lacordaire, 1835) }\end{array}$ & & & & & 1 & 0.24 \\
\hline Ampedus nigrinus (Herbst, 1784) & & & 1 & 0.32 & & \\
\hline Ampedus nigroflavus (Goeze, 1777) & & & & & 13 & 1.9 \\
\hline
\end{tabular}


Table A1. Cont.

\begin{tabular}{|c|c|c|c|c|c|c|}
\hline \multirow[b]{2}{*}{ Family, Species } & \multicolumn{2}{|c|}{2018} & \multicolumn{2}{|c|}{2019} & \multicolumn{2}{|c|}{2020} \\
\hline & $\begin{array}{l}\text { Number of } \\
\text { Specimens }\end{array}$ & $\begin{array}{c}\text { Occurrence, } \\
\%\end{array}$ & $\begin{array}{l}\text { Number of } \\
\text { Specimens }\end{array}$ & $\begin{array}{c}\text { Occurrence, } \\
\%\end{array}$ & $\begin{array}{l}\text { Number of } \\
\text { Specimens }\end{array}$ & $\begin{array}{c}\text { Occurrence, } \\
\%\end{array}$ \\
\hline Ampedus pomonae (Stephens, 1830) & & & 1 & 0.32 & 13 & 1.67 \\
\hline Ampedus pomorum (Herbst, 1784) & & & 4 & 1.26 & 97 & 9.05 \\
\hline Ampedus praeustus (Fabricius, 1792) & & & 1 & 0.32 & 13 & 1.67 \\
\hline Ampedus sanguinolentus (Schrank, 1776) & & & 3 & 0.95 & 45 & 4.05 \\
\hline Ampedus sanguineus (Linnaeus, 1758) & & & & & 3 & 0.48 \\
\hline Ampedus tristis (Linnaeus, 1758) & & & & & 1 & 0.24 \\
\hline Aplotarsus incanus (Gyllenhal, 1827) & & & 1 & 0.32 & & \\
\hline Athous haemorrhoidalis (Fabricius, 1801) & & & & & 1 & 0.24 \\
\hline Athous subfuscus (O.F. Müller, 1764) & & & 2 & 0.32 & 2 & 0.48 \\
\hline Athous vittatus (Fabricius, 1792) & & & 1 & 0.32 & 4 & 0.95 \\
\hline Cardiophorus ruficollis (Linnaeus, 1758) & & & 1 & 0.32 & 1 & 0.24 \\
\hline Dalopius marginatus (Linnaeus, 1758) & 1 & 1.2 & 24 & 3.79 & 15 & 3.33 \\
\hline Danosoma fasciatum (Linnaeus, 1758) & & & 1 & 0.32 & & \\
\hline Denticollis borealis (Paykull, 1800) & & & 1 & 0.32 & 2 & 0.48 \\
\hline Ectinus aterrimus (Linnaeus, 1760) & & & 1 & 0.32 & & \\
\hline Elater ferrugineus Linnaeus, 1758 & 2 & 2.4 & 6 & 1.89 & & \\
\hline Hemicrepidius niger (Linnaeus, 1758) & & & & & 1 & 0.24 \\
\hline Lacon lepidopterus (Panzer, 1800) & & & & & 1 & 0.24 \\
\hline Limonius minutus (Linnaeus, 1758) & & & 3 & 0.95 & 4 & 0.95 \\
\hline Melanotus castanipes (Paykull, 1800) & & & 8 & 2.52 & 9 & 1.19 \\
\hline Melanotus villosus (Geoffroy, 1785) & & & & & 5 & 0.95 \\
\hline Mosotalesus nigricornis (Panzer, 1799) & & & 3 & 0.63 & 1 & 0.24 \\
\hline Prosternon tesselatum (Linnaeus, 1758) & 1 & 1.2 & 14 & 3.47 & 124 & 9.76 \\
\hline Selatosomus aeneus (Linnaeus, 1758) & & & 1 & 0.32 & 17 & 1.43 \\
\hline Sericus brunneus (Linnaeus, 1758) & & & & & 1 & 0.24 \\
\hline \multicolumn{7}{|l|}{ Lycidae } \\
\hline Lygistopterus sanguineus (Linnaeus, 1758) & & & 8 & 1.26 & & \\
\hline \multicolumn{7}{|l|}{ Cantharidae } \\
\hline Cantharis flavilabris Fallén, 1807 & & & 1 & 0.32 & & \\
\hline Cantharis livida Linnaeus, 1758 & 12 & 2.4 & 6 & 1.26 & 196 & 4.29 \\
\hline Cantharis nigricans O.F. Müller, 1776 & 2 & 1.2 & 9 & 2.84 & 90 & 6.9 \\
\hline Cantharis pallida Goeze, 1777 & & & & & 7 & 0.95 \\
\hline Cantharis pellucida Fabricius, 1792 & & & 10 & 1.26 & 83 & 5.24 \\
\hline Cantharis rufa Linnaeus, 1758 & & & 4 & 0.95 & 1 & 0.24 \\
\hline Cantharis rustica Fallén, 1807 & 1 & 1.2 & & & 12 & 0.95 \\
\hline Malthodes guttifer Kiesenwetter, 1852 & & & & & 2 & 0.48 \\
\hline Malthodes sp. & & & & & 1 & 0.24 \\
\hline Podabrus alpinus (Paykull, 1798) & & & & & 1 & 0.24 \\
\hline Rhagonycha fulva (Scopoli, 1763) & 1 & 1.2 & & & 1 & 0.24 \\
\hline Rhagonycha fugax Mannerheim, 1843 & & & & & 4 & 0.71 \\
\hline Rhagonycha lignosa (O.F. Müller, 1764) & & & & & 4 & 0.95 \\
\hline Rhagonycha nigriventris Motschulsky, 1860 & & & & & 2 & 0.48 \\
\hline \multicolumn{7}{|l|}{ Dermestidae } \\
\hline Attagenus schaefferi (Herbst, 1792) & & & 107 & 4.42 & 16 & 2.38 \\
\hline
\end{tabular}


Table A1. Cont.

\begin{tabular}{|c|c|c|c|c|c|c|}
\hline \multirow[b]{2}{*}{ Family, Species } & \multicolumn{2}{|c|}{2018} & \multicolumn{2}{|c|}{2019} & \multicolumn{2}{|c|}{2020} \\
\hline & $\begin{array}{l}\text { Number of } \\
\text { Specimens }\end{array}$ & $\begin{array}{c}\text { Occurrence, } \\
\%\end{array}$ & $\begin{array}{l}\text { Number of } \\
\text { Specimens }\end{array}$ & $\begin{array}{c}\text { Occurrence, } \\
\%\end{array}$ & $\begin{array}{l}\text { Number of } \\
\text { Specimens }\end{array}$ & $\begin{array}{c}\text { Occurrence, } \\
\%\end{array}$ \\
\hline Anthrenus museorum (Linnaeus, 1760) & & & 1 & 0.32 & & \\
\hline Ctesias serra (Fabricius, 1792) & & & 39 & 4.42 & & \\
\hline Dermestes laniarius Illiger, 1801 & & & 1 & 0.32 & & \\
\hline Dermestes lardarius Linnaeus, 1758 & & & 1 & 0.32 & 1 & 0.24 \\
\hline Dermestinus murinus Linnaeus, 1758 & & & & & 4 & 0.71 \\
\hline Globicornis emarginata (Gyllenhal, 1808) & & & 27 & 2.52 & 17 & 2.14 \\
\hline Megatoma undata (Linnaeus, 1758) & & & 1 & 0.32 & 2 & 0.48 \\
\hline Trogoderma glabrum (Herbst, 1783) & 2 & 2.4 & 88 & 5.68 & 18 & 3.33 \\
\hline \multicolumn{7}{|l|}{ Ptinidae } \\
\hline Dorcatoma dresdensis Herbst, 1792 & & & 1 & 0.32 & & \\
\hline Dorcatoma flavicornis (Fabricius, 1792) & & & 1 & 0.32 & & \\
\hline Dorcatoma robusta A. Strand, 1938 & & & 6 & 1.58 & 1 & 0.24 \\
\hline \multicolumn{7}{|l|}{ Lymexylidae } \\
\hline Elateroides dermestoides (Linnaeus, 1760) & & & & & 1 & 0.24 \\
\hline \multicolumn{7}{|l|}{ Cleridae } \\
\hline Allonyx quadrimaculatus (Schaller, 1783) & & & 2 & 0.63 & & \\
\hline Thanasimus femoralis (Zetterstedt, 1828) & & & 3 & 0.95 & 2 & 0.48 \\
\hline Thanasimus formicarius (Linnaeus, 1758) & & & 4 & 1.26 & 3 & 0.71 \\
\hline Tillus elongatus (Linnaeus, 1758) & & & 1 & 0.32 & & \\
\hline Trichodes apiarius (Linnaeus, 1758) & 1 & 1.2 & 2 & 0.63 & 3 & 0.71 \\
\hline \multicolumn{7}{|l|}{ Melyridae } \\
\hline Cordylepherus viridis (Fabricius, 1787) & & & 1 & 0.32 & 3 & 0.71 \\
\hline Dasytes niger (Linnaeus, 1760) & 1 & 1.2 & 10 & 3.15 & 12 & 1.9 \\
\hline Dasytes fusculus (Illiger, 1801) & & & 1 & 0.32 & 7 & 0.95 \\
\hline Malachius bipustulatus (Linnaeus, 1758) & & & & & 5 & 0.95 \\
\hline \multicolumn{7}{|l|}{ Erotylidae } \\
\hline Triplax russica (Linnaeus, 1758) & & & 2 & 0.63 & 1 & 0.24 \\
\hline Tritoma subbasalis (Reitter, 1896) & & & & & 2 & 0.48 \\
\hline \multicolumn{7}{|l|}{ Monotomidae } \\
\hline Rhizophagus fenestralis (Linnaeus, 1758) & & & 15 & 2.84 & 39 & 4.29 \\
\hline \multicolumn{7}{|l|}{ Nitidulidae } \\
\hline Carpophilus hemipterus (Linnaeus, 1758) & & & 10 & 2.21 & 2 & 0.48 \\
\hline Carpophilus marginellus Motschulsky, 1858 & & & & & 2 & 0.24 \\
\hline Carpophilus sp. & & & 1 & 0.32 & & \\
\hline Cryptarcha strigata (Fabricius, 1787) & 249 & 60.7 & 1227 & 44.79 & 1406 & 48.09 \\
\hline Cryptarcha undata (G.-A. Olivier, 1790) & 8 & 3.6 & 14 & 3.78 & 105 & 8.57 \\
\hline Cychramus luteus (Fabricius, 1787) & 9 & 6 & 834 & 12.3 & 101 & 6.9 \\
\hline Cychramus variegatus (Herbst, 1792) & 4 & 1.2 & 56 & 5.05 & 15 & 1.43 \\
\hline Cyllodes ater (Herbst, 1792) & 1 & 1.2 & & & 1 & 0.24 \\
\hline Epuraea sp. & 8 & 8.3 & 268 & 15.77 & 437 & 19.52 \\
\hline Glischrochilus grandis (Tournier, 1872) & 47 & 25 & 652 & 25.24 & 4876 & 50.48 \\
\hline
\end{tabular}


Table A1. Cont.

\begin{tabular}{|c|c|c|c|c|c|c|}
\hline \multirow[b]{2}{*}{ Family, Species } & \multicolumn{2}{|c|}{2018} & \multicolumn{2}{|c|}{2019} & \multicolumn{2}{|c|}{2020} \\
\hline & $\begin{array}{l}\text { Number of } \\
\text { Specimens }\end{array}$ & $\begin{array}{c}\text { Occurrence, } \\
\%\end{array}$ & $\begin{array}{l}\text { Number of } \\
\text { Specimens }\end{array}$ & $\begin{array}{l}\text { Occurrence, } \\
\%\end{array}$ & $\begin{array}{l}\text { Number of } \\
\text { Specimens }\end{array}$ & $\begin{array}{l}\text { Occurrence, } \\
\%\end{array}$ \\
\hline Glischrochilus hortensis (Geoffroy, 1785) & 71 & 25 & 885 & 28.08 & 783 & 32.38 \\
\hline Glischrochilus quadriguttatus (Fabricius, 1777) & 1 & 1.2 & 33 & 5.68 & 3 & 0.71 \\
\hline Glischrochilus quadripunctatus (Linnaeus, 1758) & 2 & 2.4 & 96 & 11.04 & 105 & 11.19 \\
\hline Glischrochilus quadrisignatus (Say, 1835) & 2 & 2.4 & 13 & 2.52 & 75 & 6.19 \\
\hline Meligethes sp. & & & 3 & 0.63 & 6 & 0.24 \\
\hline Omosita discoidea (Fabricius, 1775) & & & 1 & 0.32 & & \\
\hline Pocadius ferrugineus (Fabricius, 1775) & & & & & 1 & 0.24 \\
\hline Soronia grisea (Linnaeus, 1758) & 47 & 21.4 & 363 & 25.24 & 654 & 39.05 \\
\hline Soronia punctatissima (Illiger, 1794) & & & 3 & 0.95 & 5 & 0.48 \\
\hline \multicolumn{7}{|l|}{ Silvanidae } \\
\hline Uleiota planatus (Linnaeus, 1760) & & & 1 & 0.32 & & \\
\hline \multicolumn{7}{|l|}{ Cucujidae } \\
\hline Pediacus depressus (Herbst, 1797) & & & 15 & 3.47 & 29 & 2.86 \\
\hline \multicolumn{7}{|l|}{ Laemophloeidae } \\
\hline Cryptolestes sp. & & & 1 & 0.32 & & \\
\hline \multicolumn{7}{|l|}{ Cerylonidae } \\
\hline Cerylon ferrugineum Stephens, 1830 & & & 2 & 0.32 & & \\
\hline Cerylon histeroides (Fabricius, 1792) & & & 1 & 0.32 & & \\
\hline \multicolumn{7}{|l|}{ Latridiidae } \\
\hline Corticaria sp. & & & & & 2 & 0.48 \\
\hline Cortinicara gibbosa (Herbst, 1793) & & & 1 & 0.32 & 1 & 0.24 \\
\hline Enicmus histrio Joy \& Tomlin, 1910 & & & 1 & 0.32 & & \\
\hline $\begin{array}{l}\text { Stephostethus pandellei (C.N.F. Brisout de Barneville, } \\
\text { 1863) }\end{array}$ & & & 2 & 0.63 & & \\
\hline \multicolumn{7}{|l|}{ Coccinellidae } \\
\hline Adalia bipunctata (Linnaeus, 1758) & & & & & 1 & 0.24 \\
\hline Adalia decempunctata (Linnaeus, 1758) & & & & & 1 & 0.24 \\
\hline Anatis ocellata (Linnaeus, 1758) & & & 1 & 0.32 & 4 & 0.95 \\
\hline Calvia decemguttata (Linnaeus, 1767) & 1 & 1.2 & 6 & 1.26 & 10 & 1.9 \\
\hline Calvia quatuordecimguttata (Linnaeus, 1758) & & & 7 & 2.21 & 14 & 2.38 \\
\hline Chilocorus renipustulatus (L.G. Scriba, 1791) & & & 2 & 0.63 & & \\
\hline Coccinella magnifica L. Redtenbacher, 1843 & & & & & 2 & 0.48 \\
\hline Coccinella septempunctata Linnaeus, 1758 & & & & & 1 & 0.24 \\
\hline Exochomus quadripustulatus (Linnaeus, 1758) & & & & & 1 & 0.24 \\
\hline Halyzia sedecimguttata (Linnaeus, 1758) & 1 & 1.2 & 5 & 1.58 & 9 & 2.14 \\
\hline Harmonia axyridis (Pallas, 1773) & & & & & 1 & 0.24 \\
\hline Harmonia quadripunctata (Pontoppidan, 1763) & & & 2 & 0.63 & 6 & 1.19 \\
\hline Hippodamia variegata (Goeze, 1777) & & & 1 & 0.32 & 1 & 0.24 \\
\hline Mysia oblongoguttata (Linnaeus, 1758) & & & 1 & 0.32 & 5 & 1.19 \\
\hline Oenopia conglobata (Linnaeus, 1758) & & & 1 & 0.32 & 2 & 0.48 \\
\hline Propylea quatuordecimpunctata (Linnaeus, 1758) & & & & & 2 & 0.48 \\
\hline Sospita vigintiguttata (Linnaeus, 1758) & & & 1 & 0.32 & 1 & 0.24 \\
\hline Vibidia duodecimguttata (Poda von Neuhaus, 1761) & & & & & 1 & 0.24 \\
\hline
\end{tabular}


Table A1. Cont.

\begin{tabular}{|c|c|c|c|c|c|c|}
\hline \multirow[b]{2}{*}{ Family, Species } & \multicolumn{2}{|c|}{2018} & \multicolumn{2}{|c|}{2019} & \multicolumn{2}{|c|}{2020} \\
\hline & $\begin{array}{l}\text { Number of } \\
\text { Specimens }\end{array}$ & $\begin{array}{c}\text { Occurrence, } \\
\%\end{array}$ & $\begin{array}{l}\text { Number of } \\
\text { Specimens }\end{array}$ & $\begin{array}{c}\text { Occurrence, } \\
\%\end{array}$ & $\begin{array}{l}\text { Number of } \\
\text { Specimens }\end{array}$ & $\begin{array}{c}\text { Occurrence, } \\
\%\end{array}$ \\
\hline \multicolumn{7}{|l|}{ Mycetophagidae } \\
\hline Litargus connexus (Geoffroy, 1785) & & & 17 & 3.47 & 11 & 1.19 \\
\hline Mycetophagus quadripustulatus (Linnaeus, 1760) & & & 1 & 0.32 & 2 & 0.48 \\
\hline \multicolumn{7}{|l|}{ Melandryidae } \\
\hline Osphya bipunctata (Fabricius, 1775) & & & & & 1 & 0.24 \\
\hline Phloiotrya subtilis (Reitter, 1897) & & & & & 1 & 0.24 \\
\hline \multicolumn{7}{|l|}{ Mordellidae } \\
\hline Tomoxia bucephala A. Costa, 1854 & & & 7 & 1.89 & 1 & 0.24 \\
\hline Mordella sp. & & & 3 & 0.63 & 1 & 0.24 \\
\hline \multicolumn{7}{|l|}{ Tenebrionidae } \\
\hline Bolitophagus reticulatus (Linnaeus, 1767) & & & & & 3 & 0.71 \\
\hline Corticeus unicolor Piller \& Mitterpacher, 1783 & & & & & 2 & 0.48 \\
\hline Lagria hirta (Linnaeus, 1758) & & & 19 & 4.73 & 3 & 0.71 \\
\hline Mycetochara axillaris (Paykull, 1799) & & & 1 & 0.32 & & \\
\hline Mycetochara flavipes (Fabricius, 1792) & & & 1 & 0.32 & 1 & 0.24 \\
\hline Upis ceramboides (Linnaeus, 1758) & & & 4 & 0.95 & 1 & 0.24 \\
\hline \multicolumn{7}{|l|}{ Oedemeridae } \\
\hline Chrysanthia geniculata W.L.E. Schmidt, 1846 & & & & & 6 & 1.19 \\
\hline Chrysanthia viridissima (Linnaeus, 1758) & 2 & 2.4 & & & 4 & 0.71 \\
\hline Nacerdes carniolica (Gistel, 1834) & & & & & 38 & 1.67 \\
\hline Oedemera femorata (Scopoli, 1763) & & & & & 1 & 0.24 \\
\hline Oedemera virescens (Linnaeus, 1767) & & & & & 1 & 0.24 \\
\hline \multicolumn{7}{|l|}{ Boridae } \\
\hline Boros schneideri (Panzer, 1796) & & & & & 1 & 0.24 \\
\hline \multicolumn{7}{|l|}{ Pyrochroidae } \\
\hline Pyrochroa coccinea (Linnaeus, 1760) & & & 1 & 0.32 & 9 & 0.71 \\
\hline Schizotus pectinicornis (Linnaeus, 1758) & & & 1 & 0.32 & 14 & \\
\hline \multicolumn{7}{|l|}{ Salpingidae } \\
\hline Salpingidae sp. & & & 1 & 0.32 & & \\
\hline Salpingus ruficollis (Linnaeus, 1760) & & & & & 1 & 0.24 \\
\hline \multicolumn{7}{|l|}{ Aderidae } \\
\hline Phytobaenus amabilis R.F. Sahlberg, 1834 & & & & & 1 & 0.24 \\
\hline \multicolumn{7}{|l|}{ Scraptiidae } \\
\hline Anaspis frontalis (Linnaeus, 1758) & 1 & 1.2 & 1 & 0.32 & 5 & 0.95 \\
\hline Anaspis thoracica (Linnaeus, 1758) & & & & & 1 & 0.24 \\
\hline \multicolumn{7}{|l|}{ Cerambycidae } \\
\hline Aegomorphus clavipes (Schrank, 1781) & 1 & 1.2 & 1 & 0.32 & & \\
\hline Alosterna ingrica (Baeckmann, 1902) & & & 1 & 0.32 & & \\
\hline Alosterna tabacicolor (De Geer, 1775) & 1 & 1.2 & 17 & 1.58 & 1 & 0.24 \\
\hline Anaesthetis testacea (Fabricius, 1781) & & & 1 & 0.32 & & \\
\hline Anastrangalia reyi (L. Heyden, 1889) & & & 1 & 0.32 & 2 & 0.48 \\
\hline Anoplodera rufipes ventralis Heyden, 1886 & & & & & 1 & 0.24 \\
\hline
\end{tabular}


Table A1. Cont.

\begin{tabular}{|c|c|c|c|c|c|c|}
\hline \multirow[b]{2}{*}{ Family, Species } & \multicolumn{2}{|c|}{2018} & \multicolumn{2}{|c|}{2019} & \multicolumn{2}{|c|}{2020} \\
\hline & $\begin{array}{l}\text { Number of } \\
\text { Specimens }\end{array}$ & $\begin{array}{c}\text { Occurrence, } \\
\%\end{array}$ & $\begin{array}{l}\text { Number of } \\
\text { Specimens }\end{array}$ & $\begin{array}{c}\text { Occurrence, } \\
\%\end{array}$ & $\begin{array}{l}\text { Number of } \\
\text { Specimens }\end{array}$ & $\begin{array}{c}\text { Occurrence, } \\
\%\end{array}$ \\
\hline Anoplodera sexguttata (Fabricius, 1775) & 1 & 1.2 & 23 & 3.15 & 1 & 0.24 \\
\hline Arhopalus rusticus (Linnaeus, 1758) & & & 5 & 0.95 & & \\
\hline Aromia moschata (Linnaeus, 1758) & 23 & 11.9 & 58 & 10.09 & 23 & 3.33 \\
\hline Chlorophorus herbstii (Brahm, 1790) & & & 1 & 0.32 & & \\
\hline Cortodera femorata (Fabricius, 1787) & & & & & 4 & 0.71 \\
\hline Dinoptera collaris (Linnaeus, 1758) & & & 4 & 1.26 & 5 & 0.95 \\
\hline Etorofus pubescens (Fabricius, 1787) & & & 1 & 0.32 & & \\
\hline Euracmaeops marginatus (Fabricius, 1781) & & & 1 & 0.32 & & \\
\hline Euracmaeops septentrionis (C.G. Thomson, 1866) & & & 1 & 0.32 & & \\
\hline Judolia sexmaculata (Linnaeus, 1758) & & & 1 & 0.32 & & \\
\hline Leiopus linnei Wallin, Nylander \& Kvamme, 2009 & & & 1 & 0.32 & 2 & 0.48 \\
\hline Leptura aurulenta Fabricius, 1793 & 2 & 2.4 & 1 & 0.32 & & \\
\hline Leptura thoracica Creutzer, 1799 & 68 & 22.6 & 751 & 31.55 & 1113 & 21.43 \\
\hline Leptura quadrifasciata Linnaeus, 1758 & 104 & 35.7 & 489 & 37.22 & 433 & 19.29 \\
\hline Lepturalia nigripes (De Geer, 1775) & 2 & 1.2 & 14 & 1.89 & 57 & 4.76 \\
\hline Lepturobosca virens (Linnaeus, 1758) & & & & & 5 & 0.48 \\
\hline Mesosa myops (Dalman, 1817) & 5 & 3.6 & 13 & 2.84 & 1 & 0.24 \\
\hline Molorchus minor (Linnaeus, 1758) & & & 3 & 0.95 & 12 & 2.38 \\
\hline Monochamus sutor (Linnaeus, 1758) & & & 1 & 0.32 & & \\
\hline Necydalis major Linnaeus, 1758 & 9 & 7.1 & 47 & 10.73 & 32 & 5.71 \\
\hline Nivellia sanguinosa (Gyllenhal, 1827) & & & 1 & 0.32 & & \\
\hline Obrium cantharinum (Linnaeus, 1767) & 1 & 1.2 & 45 & 5.68 & 104 & 7.14 \\
\hline Oedecnema gebleri (Ganglbauer, 1889) & & & & & 2 & 0.48 \\
\hline Pachyta quadrimaculata (Linnaeus, 1758) & 4 & 3.6 & 5 & 1.58 & 3 & 0.71 \\
\hline Phymatodes testaceus (Linnaeus, 1758) & & & 2 & 0.32 & 24 & 2.86 \\
\hline Plagionotus arcuatus (Linnaeus, 1758) & & & & & 2 & 0.48 \\
\hline Plagionotus detritus (Linnaeus, 1758) & 1 & 1.2 & 8 & 2.21 & 119 & 2.38 \\
\hline Prionus coriarius (Linnaeus, 1758) & & & 1 & 0.32 & & \\
\hline Purpuricenus globulicollis Dejean, 1839 & & & 5 & 0.95 & 1 & 0.24 \\
\hline Purpuricenus kaehleri (Linnaeus, 1758) & 7 & 7.1 & 124 & 11.04 & 167 & 7.62 \\
\hline Rhagium inquisitor (Linnaeus, 1758) & & & 24 & 4.73 & 10 & 1.9 \\
\hline Rhagium mordax (De Geer, 1775) & 49 & 20.2 & 422 & 24.29 & 778 & 34.05 \\
\hline Rhagium sycophanta (Schrank, 1781) & 2 & 2.4 & & & & \\
\hline Rhamnusium bicolor (Schrank, 1781) & 1 & 1.2 & & & & \\
\hline Ropalopus clavipes (Fabricius, 1775) & & & & & 1 & 0.24 \\
\hline Ropalopus macropus (Germar, 1823) & & & & & 2 & 0.24 \\
\hline Rutpela maculata (Poda von Neuhaus, 1761) & 9 & 7.1 & 20 & 3.15 & 16 & 2.38 \\
\hline Saperda scalaris (Linnaeus, 1758) & & & & & 1 & 0.24 \\
\hline Spondylis buprestoides (Linnaeus, 1758) & & & 2 & 0.63 & 1 & 0.24 \\
\hline Stenocorus meridianus (Linnaeus, 1758) & 7 & 8.3 & 93 & 11.67 & 38 & 1.9 \\
\hline Stenurella melanura (Linnaeus, 1758) & & & & & 1 & 0.24 \\
\hline Stictoleptura maculicornis (De Geer, 1775) & & & 2 & 0.63 & 2 & 0.48 \\
\hline
\end{tabular}


Table A1. Cont.

\begin{tabular}{|c|c|c|c|c|c|c|}
\hline \multirow[b]{2}{*}{ Family, Species } & \multicolumn{2}{|c|}{2018} & \multicolumn{2}{|c|}{2019} & \multicolumn{2}{|c|}{2020} \\
\hline & $\begin{array}{l}\text { Number of } \\
\text { Specimens }\end{array}$ & $\begin{array}{c}\text { Occurrence, } \\
\%\end{array}$ & $\begin{array}{l}\text { Number of } \\
\text { Specimens }\end{array}$ & $\begin{array}{c}\text { Occurrence, } \\
\%\end{array}$ & $\begin{array}{l}\text { Number of } \\
\text { Specimens }\end{array}$ & $\begin{array}{c}\text { Occurrence, } \\
\%\end{array}$ \\
\hline Stictoleptura rubra (Linnaeus, 1758) & & & 2 & 0.63 & 1 & 0.24 \\
\hline Stictoleptura variicornis (Dalman, 1817) & & & 1 & 0.32 & & \\
\hline Strangalia attenuata (Linnaeus, 1758) & & & 8 & 1.89 & 2 & 0.48 \\
\hline Trichoferus campestris (Faldermann, 1835) & 2 & 2.4 & 7 & 0.95 & 1 & 0.24 \\
\hline Xylotrechus antilope (Schoenherr, 1817) & & & 17 & 3.47 & 34 & 4.29 \\
\hline Xylotrechus arvicola (Olivier, 1795) & 1 & 1.2 & & & 2 & 0.48 \\
\hline Xylotrechus capricornus (Gebler, 1830) & & & & & 1 & 0.24 \\
\hline Xylotrechus pantherinus (Savenius, 1825) & & & 2 & 0.63 & 1 & 0.24 \\
\hline Xylotrechus rusticus (Linnaeus, 1758) & & & 3 & 0.95 & 1 & 0.24 \\
\hline \multicolumn{7}{|l|}{ Chrysomelidae } \\
\hline Altica sp. & & & 5 & 1.58 & 8 & 1.43 \\
\hline Aphthona sp. & & & & & 1 & 0.24 \\
\hline Chrysomela vigintipunctata (Scopoli, 1763) & & & & & 1 & 0.24 \\
\hline Crepidodera aurata (Marsham, 1802) & & & 1 & 0.32 & & \\
\hline Crepidodera nitidula (Linnaeus, 1758) & & & 1 & 0.32 & & \\
\hline Galerucella lineola (Fabricius, 1781) & & & 2 & 0.63 & 2 & 0.48 \\
\hline Gonioctena viminalis (Linnaeus, 1758) & & & & & 1 & 0.24 \\
\hline Hypocassida subferruginea (Schrank, 1776) & & & & & 1 & 0.24 \\
\hline Lochmaea caprea (Linnaeus, 1758) & & & 2 & 0.32 & & \\
\hline Orsodacne cerasi (Linnaeus, 1758) & & & & & 2 & 0.48 \\
\hline Phyllotreta undulata Kutschera, 1860 & & & & & 1 & 0.24 \\
\hline Plagiosterna aenea (Linnaeus, 1758) & & & 1 & 0.32 & 1 & 0.24 \\
\hline \multicolumn{7}{|l|}{ Anthribidae } \\
\hline Dissoleucas niveirostris (Fabricius, 1798) & & & & & 1 & 0.24 \\
\hline Tropideres albirostris (Schaller, 1783) & & & 2 & 0.63 & 5 & 1.19 \\
\hline \multicolumn{7}{|l|}{ Attelabidae } \\
\hline Byctiscus betulae (Linnaeus, 1758) & & & & & 1 & 0.24 \\
\hline \multicolumn{7}{|l|}{ Brentidae } \\
\hline Betulapion simile (Kirby, 1811) & & & 1 & 0.32 & 1 & 0.24 \\
\hline \multicolumn{7}{|l|}{ Curculionidae } \\
\hline Anisandrus dispar (Fabricius, 1792) & 1 & 1.2 & 386 & 10.73 & 2012 & 17.86 \\
\hline Anthonomus incurvus (Panzer, 1795) & & & 1 & 0.32 & & \\
\hline Bagous puncticollis Boheman, 1845 & & & 1 & 0.32 & & \\
\hline Brachyderes incanus (Linnaeus, 1758) & & & 2 & 0.63 & & \\
\hline Coeliodinus rubicundus (Herbst, 1795) & & & 2 & 0.63 & & \\
\hline Curculio glandium Marsham, 1802 & & & 1 & 0.32 & 1 & 0.24 \\
\hline Curculio nuсum Linnaeus, 1758 & 2 & 2.4 & 1 & 0.32 & 16 & 0.48 \\
\hline Curculio venosus (Gravenhorst, 1807) & & & 1 & 0.32 & & \\
\hline Curculio villosus Fabricius, 1781 & & & & & 4 & 0.95 \\
\hline Ellescus bipunctatus (Linnaeus, 1758) & & & 1 & 0.32 & & \\
\hline Ellescus scanicus (Paykull, 1792) & & & 1 & 0.32 & & \\
\hline
\end{tabular}


Table A1. Cont.

\begin{tabular}{|c|c|c|c|c|c|c|}
\hline \multirow[b]{2}{*}{ Family, Species } & \multicolumn{2}{|c|}{2018} & \multicolumn{2}{|c|}{2019} & \multicolumn{2}{|c|}{2020} \\
\hline & $\begin{array}{l}\text { Number of } \\
\text { Specimens }\end{array}$ & $\begin{array}{c}\text { Occurrence, } \\
\%\end{array}$ & $\begin{array}{l}\text { Number of } \\
\text { Specimens }\end{array}$ & $\begin{array}{c}\text { Occurrence, } \\
\%\end{array}$ & $\begin{array}{l}\text { Number of } \\
\text { Specimens }\end{array}$ & $\begin{array}{c}\text { Occurrence, } \\
\%\end{array}$ \\
\hline Hylastes opacus Erichson, 1836 & & & 2 & 0.63 & & \\
\hline Ips acuminatus (Gyllenhal, 1827) & & & 1 & 0.32 & & \\
\hline Ips typographus (Linnaeus, 1758) & & & & & 1 & 0.24 \\
\hline Orchestes rusci (Herbst, 1795) & & & 1 & 0.32 & 1 & 0.24 \\
\hline Phyllobius arborator (Herbst, 1797) & & & 1 & 0.32 & & \\
\hline Phyllobius argentatus (Linnaeus, 1758) & & & 6 & 1.26 & 5 & 1.19 \\
\hline Phyllobius maculicornis Germar, 1823 & & & 2 & 0.63 & 1 & 0.24 \\
\hline Phyllobius pomaceus Gyllenhal, 1834 & & & 1 & 0.32 & & \\
\hline Phyllobius pyri (Linnaeus, 1758) & & & 4 & 0.63 & 6 & 1.43 \\
\hline Pissodes piniphilus (Herbst, 1797) & & & & & 1 & 0.24 \\
\hline Polydrusus cervinus (Linnaeus, 1758) & & & 1 & 0.32 & & \\
\hline Polydrusus flavipes (De Geer, 1775) & 1 & 1.2 & 1 & 0.32 & & \\
\hline Polydrusus sp. & & & & & 1 & 0.24 \\
\hline Polydrusus tereticollis (De Geer, 1775) & & & & & 1 & 0.24 \\
\hline Polygraphus subopacus C.G. Thomson, 1871 & & & 1 & 0.32 & & \\
\hline Scolytus intricatus (Ratzeburg, 1837) & & & & & 1 & 0.24 \\
\hline Sitona ambiguus Gyllenhal, 1834 & & & & & 1 & 0.24 \\
\hline Sitona macularius (Marsham, 1802) & & & & & 1 & 0.24 \\
\hline Strophosoma capitatum (De Geer, 1775) & & & 5 & 1.26 & 7 & 1.43 \\
\hline Trypodendron signatum (Fabricius, 1792) & & & 1 & 0.32 & & \\
\hline Xyleborus saxesenii (Ratzeburg, 1837) & & & 92 & 1.26 & 123 & 3.09 \\
\hline TOTAL & 1750 & & 11,655 & & 19,864 & \\
\hline
\end{tabular}

\section{References}

1. Lindenmayer, D.B.; Cunningham, R.B.; Donelly, C.F.; Lesslie, R. On the use of landscape surrogates as ecological indicators in fragmented forests. For. Ecol. Manag. 2002, 159, 203-216. [CrossRef]

2. Mason, F.; Zapponi, L. The forest biodiversity artery: Towards forest management for saproxylic conservation. iForest Biogeosci. For. 2016, 9, 205-216. [CrossRef]

3. Bazhina, E.V. Siberian fir (Abies sibirica) state and chemical element allocation in tree crown in forest ecosystems of Protected Areas in south of Krasnoyarsk Region (Russia). Nat. Conserv. Res. 2018, 3 (Suppl. 2), 40-53. [CrossRef]

4. Uwalaka, N.O.; Muoghalu, J.I.; Osewole, A.O. Species diversity and successional dynamics in the secondary forest of Obafemi Awolowo University Biological Gardens Ile-Ife, Nigeria. Nat. Conserv. Res. 2018, 3, 21-34. [CrossRef]

5. Rozhkov, Y.F.; Kondakova, M.Y. Assessment of the post-fire forest restoration dynamics in the Olekminsky State Nature Reserve (Russia) according to data of Landsat satellite images. Nat. Conserv. Res. 2019, 4 (Suppl. 1), 1-10. [CrossRef]

6. Ruchin, A.B.; Khapugin, A.A. Red data book invertebrates in a protected area of European Russia. Acta Zool. Acad. Sci. Hung. 2019, 65, 349-370. [CrossRef]

7. Arkhipova, M.V. Forest cover changes in the center of East European plain over the last 150 years. Russ. J. For. Sci. 2020, 1, 35-45. [CrossRef]

8. Polevoi, A.V. Fungus gnats (Diptera: Bolitophilidae, Diadocidiidae, Keroplatidae, Mycetophilidae) in the Kostomuksha State Nature Reserve, Russia. Nat. Conserv. Res. 2021, 6 (Suppl. 1). [CrossRef]

9. Carnus, J.M.; Parrotta, J.; Brockerhoff, E.; Arbez, M.; Jactel, H.; Kremer, A.; Walters, B. Planted forests and biodiversity. J. For. 2006, 104, 65-77.

10. Cicort-Lucaciu, A.S. Road-killed ground beetles prove the presence of Carabus hungaricus (Coleoptera: Carabidae) in NorthWestern Romania. Nat. Conserv. Res. 2020, 5, 134-138. [CrossRef]

11. Thuiller, W. Biodiversity-climate change and the ecologist. Nature 2007, 448, 550-552. [CrossRef] [PubMed]

12. Ruchin, A.B.; Egorov, L.V. Overview of insect species included in the Red Data Book of Russian Federation in the Mordovia State Nature Reserve. Nat. Conserv. Res. 2017, 2 (Suppl. 1), 2-9. (In Russian) [CrossRef] 
13. Kovac, M.; Hladnik, D.; Kutnar, L. Biodiversity in (the Natura 2000) forest habitats is not static: Its conservation calls for an active management approach. J. Nat. Conserv. 2018, 43, 250-260. [CrossRef]

14. Aleinikov, A.A. The fire history in pine forests of the plain area in the Pechora-Ilych Nature Biosphere Reserve (Russia) before 1942: Possible anthropogenic causes and long-term effects. Nat. Conserv. Res. 2019, 4 (Suppl. 1), 21-34. [CrossRef]

15. Ruchin, A.B.; Alekseev, S.K.; Khapugin, A.A. Post-fire fauna of carabid beetles (Coleoptera, Carabidae) in forests of the Mordovia State Nature Reserve (Russia). Nat. Conserv. Res. 2019, 4 (Suppl. 1), 11-20. [CrossRef]

16. Dedyukhin, S.V. Phytophagous beetles (Coleoptera: Chrysomelidae and Curculionoidea), protected and recommended for protection in the regions of the Middle Volga and the Urals. Nat. Conserv. Res. 2020, 5, 1-27. (In Russian) [CrossRef]

17. Stork, N.E.; Grimbacher, P.S. Beetle assemblages from an Australian tropical rainforest show that the canopy and the ground strata contribute equally to biodiversity. Proc. Biol. Sci. 2006, 273, 1969-1975. [CrossRef] [PubMed]

18. Dodds, K.J. Effects of trap height on captures of arboreal insects in pine stands of northeastern United States of America. Can. Entomol. 2014, 146, 80-89. [CrossRef]

19. Skvarla, M.J.; Dowling, A.P.G. A comparison of trapping techniques (Coleoptera: Carabidae, Buprestidae, Cerambycidae, and Curculionoidea excluding Scolytinae). J. Insect Sci. 2017, 17, 1-28. [CrossRef]

20. Tomaszewska, W.; Egorov, L.V.; Ruchin, A.B.; Vlasov, D.V. First record of Clemmus troglodytes (Coleoptera: Coccinelloidea, Anamorphidae) for the fauna of Russia. Nat. Conserv. Res. 2018, 3, 103-105. [CrossRef]

21. Volf, M.; Klimeš, P.; Lamarre, G.P.A.; Redmond, C.M.; Seifert, C.L.; Abe, T.; Auga, J.; Anderson-Teixeira, K.; Basset, Y.; Beckett, S.; et al. Quantitative assessment of plant-arthropod interactions in forest canopies: A plot-based approach. PLoS ONE 2019, 14, e0222119. [CrossRef]

22. Bondarenko, A.S.; Zamotajlov, A.S.; Belyi, A.I.; Khomitskiy, E.E. Fauna and ecological characteristics of ground beetles (Coleoptera, Carabidae) of the Nature Sanctuaries "Prichernomorskiy" and "Tuapsinskiy" (Russia). Nat. Conserv. Res. 2020, 5, 66-85. [CrossRef]

23. Jackman, J.A.; Nelson, C.R. Diversity and phenology of tumbling flower beetles (Coleoptera: Mordellidae) captured in a Malaise trap. Entomol. News 1995, 106, 97-107.

24. Leksono, A.S.; Takada, K.; Koji, S.; Nakagoshi, N.; Anggaeni, T.; Nakamura, K. Vertical and seasonal distribution of flying beetles in a suburban temperate deciduous forest collected by water pan trap. Insect Sci. 2005, 12, 199-206. [CrossRef]

25. Marques, M.I.; Adis, J.; Brizzola dos Santos, G.; Battirola, L.D. Terrestrial arthropods from tree canopies in the Pantanal of Mato Grosso, Brazil. Rev. Bras. Entomol. 2006, 50, 257-267. [CrossRef]

26. Campbell, J.W.; Hanula, J.L. Efficiency of Malaise traps and colored pan traps for collecting flower visiting insects from three forested ecosystems. J. Insect Conserv. 2007, 11, 399-408. [CrossRef]

27. Hodge, S.; Marshall, S.A.; Oliver, H.; Berry, J.; Marris, J.; Andrew, I. A preliminary survey of the insects collected using mushroom baits in native and exotic New Zealand woodlands. N. Z. Entomol. 2010, 33, 43-54. [CrossRef]

28. Fagundes, C.K.; Di Mare, R.A.; Wink, C.; Manfio, D. Diversity of the families of Coleoptera captured with pitfall traps in five different environments in Santa Maria, RS, Brazil. Braz. J. Biol. 2011, 71, 381-390. [CrossRef]

29. Schmeelk, T.C.; Millar, J.G.; Hanks, L.M. Influence of trap height and bait type on abundance and species diversity of cerambycid beetles captured in forests of East-Central Illinois. J. Econ. Entomol. 2016, 109, 1750-1757. [CrossRef] [PubMed]

30. Alexeev, S.C.; Aleksanov, V.V. Pitfall trap construction affects the efficacy of ground beetle counts. Zool. Zhurnal 2017, 96, 295-304. [CrossRef]

31. Byk, A.; Wegrzynowicz, P. The Structure and Seasonal Dynamics of Coprophagous Scarabaeoidea (Coleoptera) Communities in Later Developmental Stages of Pine Stands in NW Poland. J. Entomol. Res. Soc. 2015, 17, 39-57.

32. Kazantsev, S.V.; Egorov, L.V.; Ruchin, A.B. Discovery of Lopheros lineatus (Gorham, 1883) (Coleoptera, Lycidae) in Mordovia, Central Russia. Entomol. Rev. 2019, 99, 656-659. [CrossRef]

33. MacRae, T.C. Beetle Collecting 101: Fermenting Bait Traps for Collecting Longhorned Beetles. 2015. Available online: https:/ / beetlesinthebush.wordpress.com/2015/12/28/beetle-collecting-101-fermenting-bait-traps-for-collecting-longhorned-beetles / (accessed on 3 October 2020).

34. Hodge, S.; Williams, A. Beetles collected using rotting vegetable baits in a Kent Garden. Entomol. Mon. Mag. 2011, 146, 179-188.

35. Allemand, R.; Aberlenc, H.-P. Une méthode efficace d'echantillonage de l'entomofaune des frondaisons: Le piège attractif aérien. Bull. Société Entomol. Suisse 1991, 64, 293-305.

36. Williams, R.N.; Ellis, M.S.; Keeney, G. A bait attractant study of the Nitidulidae (Coleoptera) at Shawnee State Forest in Southern Ohio. Great Lakes Entomol. 1995, 27, 229-234.

37. MacRae, T.C.; Rice, M.E. Distributional and biological observations on North American Cerambycidae (Coleoptera). Coleopt. Bull. 2007, 61, 227-263. [CrossRef]

38. Guarnieri, F.G. A survey of longhorned beetles (Coleoptera: Cerambycidae) from Paw Paw, Morgan County, West Virginia. Md. Entomol. 2009, 5, 11-22.

39. Bardiani, M.; Tini, M.; Carpaneto, G.M.; Audisio, P.; Bussola, E.; Campanaro, A.; Cini, A.; Maurizi, E.; Mason, F.; Peverieri, G.S.; et al. Effects of trap baits and height on stag beetle and lower chafer monitoring: Ecological and conservation implications. J. Insect Conserv. 2017, 21, 157-168. [CrossRef]

40. Redolfi De Zan, L.; Bardiani, M.; Antonini, G.; Campanaro, A.; Chiari, S.; Mancini, E.; Maura, M.; Sabatelli, S.; Solano, E.; Zauli, A.; et al. Guidelines for the monitoring of Cerambyx cerdo. Nat. Conserv. 2017, 20, 129-164. [CrossRef] 
41. Rukavina, I.; Kostanjšek, F.; Jelaska, S.D.; Pirnat, A.; Šerić, J.L. Distribution and habitat suitability of two rare saproxylic beetles in Croatia-A piece of puzzle missing for South-Eastern Europe. iForest 2018, 11, 765-774. [CrossRef]

42. Barros, R.C.; Fonseca, M.G.; Jardim, M.T.; Vendramini, V.E.; Damiani, B.C.B.; Julio, C.E.A. Species of Cerambycinae (Insecta, Coleoptera, Cerambycidae) from east Paraná State (Brazil), with new geographic records. Zootaxa 2020, 4845, 001-025. [CrossRef]

43. Ruchin, A.B.; Egorov, L.V.; Khapugin, A.A. Seasonal activity of Coleoptera attracted by fermental crown traps in forest ecosystems of Central Russia. Ecol. Quest. 2021, 32, 37-53. [CrossRef]

44. Dvořák, L.; Dvořáková, K.; Oboňa, J.; Ruchin, A.B. Selected Diptera families caught with beer traps in the Republic of Mordovia (Russia). Nat. Conserv. Res. 2020, 5, 65-77. [CrossRef]

45. Ruchin, A.B.; Egorov, L.V. The beetles (Insecta: Coleoptera) of Smolny National Park (based on insect collecting by fermental crown traps in 2020). Sci. Proc. State Nat. Reserve Prisursky 2020, 35, 221-225. (In Russian)

46. Ruchin, A.B.; Egorov, L.V.; Khapugin, A.A.; Vikhrev, N.E.; Esin, M.N. The use of simple crown traps for the insects collection. Nat. Conserv. Res. 2020, 5, 87-108. [CrossRef]

47. MacRae, T.C. Review of the genus Purpuricenus Dejean (Coleoptera: Cerambycidae) in North America. Pan-Pac. Entomol. 2000, 76, 137-169.

48. Philips, T.K.; Whorrall, K.A.; Gearner, O.M.; Huchet, J.B. A new genus of spider beetle (Coleoptera, Ptinidae) from western Peru. ZooKeys 2020, 934, 81-91. [CrossRef]

49. Ruchin, A.B.; Egorov, L.V. Beetles (Insecta, Coleoptera), collected using fermental crown trap in the Republic of Mordovia. Report. 1. Mordovia State Nature Reserve. Sci. Proc. State Nat. Reserve Prisursky 2018, 33, 209-215. (In Russian)

50. Bouchard, P.; Bousquet, Y.; Davies, A.E.; Alonso-Zarazaga, M.A.; Lawrence, J.F.; Lyal, C.H.C.; Newton, A.F.; Ried, C.A.M.; Schmitt, M.; Ślipiński, S.A.; et al. Family-group names in Coleoptera (Insecta). ZooKeys 2011, 88, 1-972. [CrossRef]

51. Bouchard, P.; Bousquet, Y. Additions and corrections to "Family-group names in Coleoptera (Insecta)". ZooKeys 2020, 922, 65-139. [CrossRef] [PubMed]

52. Löbl, I.; Smetana, A. (Eds.) Catalogue of Palaearctic Coleoptera. Vol. 7: Curculionoidea I; Apollo Books: Stenstrup, Denmark, $2011 ;$ p. 373.

53. Löbl, I.; Smetana, A. (Eds.) Catalogue of Palaearctic Coleoptera. Vol. 8: Curculionoidea II; Apollo Books: Stenstrup, Denmark, $2013 ;$ p. 707.

54. Löbl, I.; Löbl, D. (Eds.) Catalogue of Palaearctic Coleoptera. Vol. 2/1. Revised and Updated Version. Hy-Drophiloidea-Staphylinoidea; Brill: Leiden, The Netherlands; Boston, MA, USA, 2015; p. 1702.

55. Löbl, I.; Löbl, D. (Eds.) Catalogue of Palaearctic Coleoptera. Vol. 3. Revised and Updated Version. Scara-Baeoidea-Scirtoidea-DascilloideaBuprestoidea-Byrrhoidea; Brill: Leiden, The Netherlands; Boston, MA, USA, 2016; p. 983.

56. Löbl, I.; Löbl, D. (Eds.) Catalogue of Palaearctic Coleoptera. Vol. 1. Revised and Updated Version. Archostemata-Adephaga-Myxophaga; Brill: Leiden, The Netherlands; Boston, MA, USA, 2017; p. 1443.

57. Iwan, D.; Löbl, I. (Eds.) Catalogue of Palaearctic Coleoptera. Vol. 5. Revised and Updated Second Edition. Tenebrionoidea; Brill: Leiden, The Netherlands; Boston, MA, USA, 2020; p. 945.

58. Danilevsky, M. (Ed.) Catalogue of Palaearctic Coleoptera. Vol. 6/1. Updated and Revised Second Edition. Chrysomeloidea I (Vesperidae, Disteniidae, Cerambycidae); Brill: Leiden, The Netherlands; Boston, MA, USA, 2020; p. 712.

59. Robertson, J.; Ślipiński, A.; Moulton, M.; Shockley, F.W.; Giorgi, A.; Lord, N.P.; McKenna, D.D.; Tomaszewska, W.; Forrester, J.; Miller, K.B.; et al. Phylogeny and classification of Cucujoidea and the recognition of a new superfamily Coccinelloidea (Coleoptera: Cucujiformia). Syst. Entomol. 2015, 40, 745-778. [CrossRef]

60. Alonso-Zarazaga, M.A.; Barrios, H.; Borovec, R.; Bouchard, P.; Caldara, R.; Colonnelli, E.; Gültekin, L.; Hlaváč, P.; Korotyaev, B.; Lyal, C.H.C.; et al. Cooperative Catalogue of Palaearctic Coleoptera Curculionoidea. Monogr. Electrón. SEA 2017, 8, 1-729.

61. Löbl, I.; Smetana, A. (Eds.) Catalogue of Palaearctic Coleoptera. Vol. 4. Elateroidea-Derodontoidea-Bos-trichoidea-LymexyloideaCleroidea-Cucujoidea; Apollo Books: Stenstrup, Denmark, 2007; p. 935.

62. Löbl, I.; Smetana, A. (Eds.) Catalogue of Palaearctic Coleoptera. Vol. 6: Chrysomeloidae; Apollo Books: Stenstrup, Denmark, $2010 ;$ p. 924.

63. Bousquet, Y. Litteratura Coleopterologica (1758-1900): A guide to selected books related to the taxonomy of Coleoptera with publication dates and notes. ZooKeys 2016, 583, 1-776. [CrossRef]

64. Red Data Book of Vladimir Region; TPS Publ.: Tambov, Russia, 2018; p. 432. (In Russian)

65. Red Data Book of the Nizhny Novgorod Region. Vol. 1: Animals; DEKOM Publ.: Nizhny Novgorod, Russia, 2014; p. 448. (In Russian)

66. Red Data Book of Penza Region. Vol. 2. Animals; E. A. Bolkhovitinov Publ.: Voronezh, Russia, 2019; p. 264. (In Russian)

67. Red Data Book of the Republic of Mordovia. Vol. 2: Animals; Mordovia Book Publ.: Saransk, Russia, 2015; p. 336. (In Russian)

68. Red Data Book of Ryazan Region; Golos Gubernii Publ.: Ryazan, Russia, 2011; p. 626. (In Russian)

69. Red Data Book of Saratov Region; Papirus Ltd.: Saratov, Russia, 2021; p. 496. Available online: http://redbook.ch56058.tmweb.ru/ \#page $=300$ (accessed on 3 October 2020). (In Russian)

70. Red Data Book of the Tambov Region; Yulis Publ.: Tambov, Russia, 2012; p. 352. (In Russian)

71. Red Data Book of Ulyanovsk Region; Buki Vedi Publ.: Ulyanovsk, Russia, 2015; p. 550. (In Russian)

72. List of Objects of the Animal World Listed in the Red Book of the Russian Federation. 2020. Available online: https://minjust. consultant.ru/documents / 45937 (accessed on 11 May 2020). (In Russian).

73. Basset, Y. Invertebrates in the canopy of tropical rain forests. How much do we really know? Plant. Ecol. 2001, 153, 87-107. [CrossRef]

74. McCaig, T.; Sam, L.; Nakamura, A.; Stork, N.E. Is insect vertical distribution in rainforests better explained by distance from the canopy top or distance from the ground? Biodivers. Conserv. 2020, 29, 1081-1103. [CrossRef] 
75. Lowman, M.D. Canopy research in the twenty-first century: A review of Arboreal Ecology. Trop. Ecol. 2009, 50, 125-136.

76. Neves, F.S.; Araújo, L.S.; Espírito-Santo, M.M.; Fagundes, M.; Fernandes, G.W.; Sanchez-Azofeifa, G.A.; Quesada, M. Canopy herbivory and insect herbivore diversity in a dry forest-savanna transition in Brazil. Biotropica 2010, 42, 112-118. [CrossRef]

77. Nadkarni, N.M.; Parker, G.G.; Lowman, M.D. Forest canopy studies as an emerging field of science. Ann. For. Sci. 2011, 68, 217. [CrossRef]

78. Viana-Junior, A.B.; Quijano-Cuervo, L.G.; Ferreira, J.C.; do Nascimento Reis, R.R.; dos Santos, I.A.; Martins, M.B. Collecting arboreal arthropods: A technique for sampling plant-inhabiting arthropod communities in a tropical forest understory. Entomol. Exp. Et Appl. 2021, 169, 312-321. [CrossRef]

79. Sanchez-Gracia, A.; Vieira, F.G.; Almeida, F.C.; Rozas, J. Comparative genomics of the major chemosensory gene families in Arthropods. In Encyclopedia of Life Sciences; John Wiley \& Sons, Ltd.: Chichester, UK, 2011.

80. Engsontia, P.; Sangket, U.; Chotigeat, W.; Satasook, C. Molecular Evolution of the Odorant and Gustatory Receptor Genes in Lepidopteran Insects: Implications for Their Adaptation and Speciation. J. Mol. Evol. 2014, 79, 21-39. [CrossRef] [PubMed]

81. Xu, W. How do moth and butterfly taste?-Molecular basis of gustatory receptors in Lepidoptera. Insect Sci. 2020, $27,1148-1157$. [CrossRef] [PubMed]

82. Kent, L.; Robertson, H. Evolution of the sugar receptors in insects. BMC Evolutionary Biology 2009, 9, 41. [CrossRef]

83. Tooming, E.; Merivee, E.; Must, A.; Luik, A.; Williams, I.H. Antennal sugar sensitivity in the click beetle Agriotes obscurus. Physiol. Entomol. 2012, 37, 345-353. [CrossRef]

84. Stensmyr, M.C.; Larsson, M.C.; Bice, S.; Hansson, B.S. Detection of fruit- and flower-emitted volatiles by olfactory receptor neurons in the polyphagous fruit chafer Pachnoda marginata (Coleoptera: Cetoniinae). J. Comp. Physiol. A 2001, 187, 509-519. [CrossRef]

85. Leroy, P.D.; Heuskin, S.; Sabri, A.; Verheggen, F.J.; Farmakidis, J.; Lognay, G.; Thonart, P.; Wathelet, J.-P.; Brostaux, Y.; Haubruge, E. Honeydew volatile emission acts as a kairomonal message for the Asian lady beetle Harmonia axyridis (Coleoptera: Coccinellidae). Insect Sci. 2012, 19, 498-506. [CrossRef]

86. Kirmse, S.; Chaboo, C.S. Flowers are essential to maintain high beetle diversity (Coleoptera) in a Neotropical rainforest canopy. J. Nat. Hist. 2020, 54, 1661-1696. [CrossRef]

87. Tauzin, P. Ethologie et chorologie de Protaetia (Liocola) lugubris Herbst, 1786 sur le territoire français (Coleoptera, Cetoniidae, Cetoniinae, Cetoniini). Cetoniimania 2006, 3, 4-38.

88. Oleksa, A.; Chybicki, I.J.; Gawronski, R.; Svensson, G.P.; Burczyk, J. Isolation by distance in saproxylic beetles may increase with niche specialization. J. Insects Conserv. 2013, 17, 219-233. [CrossRef]

89. Urban, P.; Schulze, W. Ein aktueller Nachweis des Marmorierten Rosenkäfers Protaetia marmorata (Fabricius, 1792) in der Senne (Nordrhein-Westfalen) (Mitteilungen zur Insektenfauna Westfalens XXII). Mitt. Der Arb. Westfälischer Entomol. 2017, $33,15-19$.

90. Kurochkin, A.S. Fauna and bionomy of sap beetles (Coleoptera, Nitidulidae) and kateretid beetles (Coleoptera, Kateretidae) of Krasnosamarskoe forestry farm (Samara Region, Russia). Vestn. Samara Univ. Nat. Sci. Ser. 2007, 8, 120-128. (In Russian)

91. Alekseev, V.I.; Nikitsky, N.B. Rare and new for the fauna of the Baltic States Beetles (Coleoptera) from the Kaliningrad region. Acta Zool. Litu. 2008, 18, 254-259. [CrossRef]

92. Lason, A.; Holly, M. Glischrochilus grandis Tournier, 1872-New species of beetle for the Polish fauna and new data on the occurrence of genus Glischrochilus Reitter, 1873 (Coleoptera: Nitidulidae: Cryptarchinae). Acta Entomol. Sil. 2015, $23,1-4$.

93. Nikitsky, N.B.; Osipov, I.N.; Chemeris, M.V.; Semenov, V.B.; Gusakov, A.A. The beetles of the Prioksko-Terrasny Biosphere Reserve-Xylobiontes, mycetobiontes and Scarabaeidae. Arch. Zool. Mus. Mosc. State Univ. 1996, XXXVI, 1-197. (In Russian)

94. Nikitsky, N.B.; Mamontov, S.N.; Vlasenko, A.S. New data of beetles from Tula abatis forests (Coleoptera: Nitidulidae-Scolytidae) collected in window traps. Bull. Mosc. Soc. Nat. Biol. Ser. 2016, 121, 25-37. (In Russian)

95. Clayhills, T. Coleoptera species new to Finland (1) (Coleoptera). Koleopterol. Rundsch. 2011, 81, 311-319.

96. Tauzin, P. Chorologie et éco-éthologie de Protaetia (Potosia) fieberi Kraatz 1880 en France (Coleoptera, Cetoniinae, Cetoniini). Cetoniimania 2007, 3, 115-146.

97. Ruchin, A.B.; Egorov, L.V.; Sazhnev, A.S.; Polumordvinov, O.A.; Ishin, R.N. Present distribution of Protaetia fieberi (Kraatz, 1880) (Insecta, Coleoptera, Scarabaeidae) in the European part of Russia. Biharean Biol. 2019, 13, 12-16.

98. Bílý, S.; Mehl, O. Longhorn Beetles (Coleoptera, Cerambycidae) of Fennoscandia and Denmark; Brill: Leiden, The Netherlands, $1989 ;$ p. 200.

99. Avgin, S.S.; Antonini, G.; Lasoń, A.; Jansson, N.; Abacigil, T.Ö.; Varli, S.V.; De Biase, A.; Audisio, P. New data on distribution, ecology, and taxonomy of Turkish Nitidulidae (Coleoptera). Turk. J. Zool. 2015, 29, 314-322. [CrossRef]

100. Oude, J.E. Naamlijst van de glanskevers van Nederland en het omliggende gebied (Coleoptera: Nitidulidae and Brachypteridae). Ned. Faun. Meded. 1999, 8, 11-32.

101. Ruchin, A.B.; Egorov, L.V. Fauna of longicorn beetles (Coleoptera: Cerambycidae) of Mordovia. Russ. Entomol. J. 2018, 27, 161-177. [CrossRef]

102. Cherepanov, A.I. The Longhorn Beetles of Northern Asia (Prioninae, Disteniinae, Lepturinae, Aseminae); Nauka Publ.: Novosibirsk, Russia, 1979; p. 472.

103. Gutowski, J.M.; Ługowoj, J.; Maciejewski, K.H. Leptura thoracica Creutzer, 1799 (Coleoptera: Cerambycidae) in Poland. Wiad. Entomol. 1994, 13, 157-165. (In Polish)

104. Sama, G. Atlas of the Cerambycidae of Europe and the Mediterranean Area. Vol. 1. Northern, Western, Central and Eastern Europe British Isles and Continental Europe from France (Excl. Corsica) to Scandinavia and Urals; Kabourek: Zlín, Czechia, $2002 ;$ p. 173. 
105. Karpiński, L.; Szczepański, W.T.; Boldgiv, B.; Walczak, M. New data on the longhorn beetles of Mongolia with particular emphasis on the genus Eodorcadion Breuning, 1947 (Coleoptera, Cerambycidae). ZooKeys 2018, 739, 107-150. [CrossRef]

106. Danilevsky, M.L.; Ruchin, A.B.; Egorov, L.V. Mass collection of two rare longicorn-species (Coleoptera, Cerambycidae) in Central Russia. Humanit. Space 2019, 8, 1179-1183.

107. Karolyi, F.; Gorb, S.N.; Krenn, H.W. Trapping pollen by the moist mouth: Structure and function of the mouthparts in the flower visiting Cetonia aurata (Scarabeidae, Coleoptera). Arthropod Plant. Interact. 2009, 3, 1-8. [CrossRef]

108. Landvik, M.; Niemelä, P.; Roslin, T. Mother knows the best mould: An essential role for non-wood dietary components in the life cycle of a saproxylic scarab beetle. Oecologia 2016, 182, 163-176. [CrossRef]

109. Strassen, R. Zur Oekologie des Velleius dilatatus Fabricius, eines als Raumgast bei Vespa crabro Linnaeus lebenden Staphyliniden (Insecta, Coleoptera). Z. Für Morphol. Und Ökologie Der Tiere 1957, 46, 243-292. (In German) [CrossRef]

110. Konwerski, S.; Melke, A.; Miłkowski, M.; Ruta, R.; Sienkiewicz, P. Nowe stanowiska Velleius dilatatus (Fabricius, 1787) w Polsce (Coleoptera: Staphylinidae) oraz uwagi o jego ochronie. Chronmy Przyr. Ojczystą 2010, 66, 111-115. (In Polish)

111. Burakowski, B.; Mroczkowski, M.; Stefańska, J. Chrząszcze Coleoptera, Scarabaeoidea, Dascilloidea, Byrrhoidea i Parnoidea. Kat. Fauny Pol. 1983, 23, 9.

112. Parmentier, T.; Dekoninck, W.; Wenseleers, T. A highly diverse microcosm in a hostile world: A review on the associates of red wood ants (Formica rufa group). Insectes Sociaux 2014, 61, 229-237. [CrossRef]

113. Valdés, E.M.E.; Aldana, L.L.; Figueroa, B.; Gutiérrez, M.O.; Hernández, R.M.C.; Chavelas, M.T. Trapping of Scyphophorus acupunctatus (Coleoptera: Curculionidae) with two natural baits in a field of Polianthes tuberosa (Liliales: Agavaceae) in the state of Morelos, México. Fla. Entomol. 2005, 88, 338-340. [CrossRef]

114. Yang, K.-L.; Wen, X.-J.; Zhang, G.-Y.; Wen, J.-B. Evaluation of trap designs and food attractants for trapping Eucryptorrhynchus scrobiculatus (Coleoptera: Curculionidae). Biocontrol Sci. Technol. 2019, 29, 28-43. [CrossRef]

115. Bardiani, M.; Chiari, S.; Maurizi, E.; Tini, M.; Toni, I.; Zauli, A.; Campanaro, A.; Carpaneto, G.M.; Audisio, P. Guidelines for the monitoring of Lucanus cervus. Nat. Conserv. 2017, 20, 37-78. [CrossRef]

116. Mudge, A.D.; Orozco, J.; Philips, T.K.; Antoine, P. The cetoniine fauna of the Upper Guinean forests and savannas of Ghana (Coleoptera: Scarabaeidae: Cetoniinae). Terr. Arthropod Rev. 2012, 5, 113-174. [CrossRef]

117. Correa, C.M.A.; Puker, A.; Lara, M.A.; Rosa, C.S.; Korasaki, V. Evaluation of baits for trapping of Neotropical flower chafer beetles (Coleoptera: Scarabaeoidea: Cetoniinae). Entomol. Sci. 2019, 22, 365-372. [CrossRef]

118. Wong, J.C.H.; Hanks, L.M. Influence of fermenting bait and vertical position of traps on attraction of cerambycid beetles to pheromone lures. J. Econ. Entomol. 2016, 109, 2145-2150. [CrossRef]

119. Ausden, M.; Drake, M. Invertebrates. In Ecological Census Techniques, a Handbook, 2nd ed.; Sutherland, W.J., Ed.; Cambridge University Press: Cambridge, UK, 2006; pp. 214-249.

120. Laaksonen, J.; Laaksonen, T.; Itämies, J.; Rytkönen, S.; Välimäki, P. A new efficient bait-trap model for Lepidoptera surveys-The «Oulu» model. Entomol. Fenn. 2006, 17, 153-160. [CrossRef]

121. Makarkin, V.N.; Ruchin, A.B. New data on Neuroptera and Raphidioptera of Mordovia (Russia). Kavk. Entomol. Bull. 2019, 15, 147-157. (In Russian) [CrossRef] 